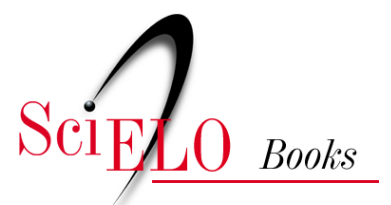

\title{
1. Questões Conceituais da Bioética Clínica é possível uma metabioética realista?
}

\author{
Fermin Roland Schramm
}

SHRAMM, F. R. Questões Conceituais da Bioética Clínica: é possível uma metabioética realista?. In: Três ensaios de bioética [online]. Rio de Janeiro: Editora FIOCRUZ, 2015, pp. 19-66. ISBN: 978-857541-586-3. https://doi.org/10.7476/9788575415863.0003. International license.

Todo o conteúdo deste trabalho, exceto quando houver ressalva, é publicado sob a licença Creative Commons Atribição $\underline{4.0}$. 


\section{Questões Conceituais da Bioética Clínica: é possível uma metabioética realista?*}

A pergunta se é possível uma metabioética realista pode parecer descabida, por supostamente remeter a uma contradictio in terminis, em consequência de um raciocínio errado e, portanto, não pertinente nem justificada. O argumento que se pode aduzir é que o neologismo metabioética (aqui proposto) só poderia ser usado com pertinência se - de acordo com a distinção entre ética e metaética - entendêssemos metabioética como atividade ou ferramenta que só se ocuparia dos conceitos e métodos utilizados pela bioética, constituindo, portanto, um discurso de segunda ordem. Este teria por objeto de análise o(s) discurso(s) de primeira ordem, representado(s) pelas reflexões e julgamentos morais referidos a questões empíricas (como o modo correto, ou não, de se comportar em determinada situação conflituosa). Ademais, o adjetivo realista só se aplicaria à representação de objetos concretos; ou seja, pertenceria a uma concepção que considera o real como independente e preexistente às ideias que podemos ter (e construir) sobre ele - e que deve, por isso, ser em princípio distinto, embora não necessariamente separado (pelo menos se adotarmos uma postura construtivista), dos conceitos (ou ideias) que lhe aplicamos (ou construímos sobre ele).

\footnotetext{
* Reelaboração e ampliação do artigo "Questões conceituais e metaéticas da bioética clínica: uma introdução”, publicado na revista Bioethikos, 6(2): 125-132, 2012.
} 
Dito de maneira um pouco mais precisa, a metabioética se referiria, por definição, a uma atividade de segunda ordem que consiste em uma análise crítica dos conceitos, juízos e argumentos morais utilizados em uma disputa, assim como dos métodos utilizados pela bioética. Preocupa-se, portanto, tanto com problemas semânticos (como o significado dos termos morais utilizados, que pode não ser o mesmo entre os atores envolvidos) e problemas lógicos (como a cogência - ou validade - dos argumentos morais em campo) quanto com problemas ontológicos (como a existência e a identidade dos fatos morais analisados) e problemas epistemológicos (que dizem respeito à natureza de tais fatos morais e à pertinência do conhecimento moral), e que devem ser distintos dos problemas normativos (referentes àquilo que deve ser feito) (Mautner, 2010a).

Em outros termos, a metabioética (entendida como campo de objetos de segunda ordem) não deveria se preocupar diretamente com os problemas práticos (ou normativos) de primeira ordem, que se referem ao comportamento concreto resultante dos deveres e regras morais que deveriam orientá-lo. A metabioética teria, portanto, como objeto de estudo não tanto o comportamento e os atos humanos pertinentes para a bioética, mas as maneiras como os seres humanos representam, analisam, valorizam e justificam tais atos, realizando sua vida moral de maneira consciente, crítica e responsável, no contexto amplo do mundo vital (ou Lebenswelt), cada vez mais formado e modificado pelas competências humanas específicas de transformação de sua infraestrutura pela economia e pela biotecnociência. Assim sendo, se aceitarmos a distinção lógica entre problemas de primeira ordem e de segunda ordem, não poderemos, a rigor, falar em metabioética realista, pois o termo poderia ser considerado como resultado de uma confusão entre a ordem referida àquilo que é e a ordem daquilo que simbolizamos a partir daquilo que é.

Entretanto, aqui defenderemos a tese de que é possível uma metabioética realista, considerada uma das ferramentas analíticas da forma de ética aplicada conhecida como bioética, e que pode ser vista como pertinente e legítima se considerarmos que a separação entre primeira e segunda ordem "tende a se desvanecer porque as diferenças nas concepções sobre a estrutura [da bioética] têm implicações para os problemas de primeira ordem, relativos à tomada de decisão" (Blackburn, 1997b: 246). Embora isso não implique que devemos 
também renunciar a distingui-las, como tentaremos mostrar a seguir, apresentando o debate entre realismo e idealismo, que se complexifica quando referido às discussões em bioética clínica.

\section{Realismo versus Idealismo?}

Desde pelo menos o surgimento da filosofia moderna, o realismo defende opondo-se ao idealismo - a ideia da "precedência do mundo objetivo sobre a cognição humana, que se limita a fornecer significado ou compreensão a uma realidade autônoma e previamente existente" (Houaiss \& Villar, 2001: 2.391). Nesse contexto, uma metabioética realista parece ser uma contradictio in terminis, pois a expressão confundiria ordens separadas e, portanto, deveria ser evitada, em nome da clareza conceitual e discursiva. Entretanto, a expressão será aqui mantida, pois o próprio significado do termo realismo não é unívoco, visto que "varia com o contexto em que é usado" (Mautner, 2010c: 632), devendo-se, portanto, adjetivar a palavra (neste caso um substantivo) para se obter um sentido mais preciso e que se refira a tipos de objetos e de problemas específicos, como tentaremos mostrar a seguir.

\section{Concepções de realismo e idealismo}

Quando se pensa em uma tipologia dos realismos existentes, pode-se falar, por exemplo, em realismo ontológico (ou "teoria acerca do que há"); em realismo conceptual (referido à "tese de que os universais existem independente e objetivamente, não devendo a sua existência aos particulares individuais de que são atributos, nem ao facto de serem concebidos por uma mente" ${ }^{\prime \prime}$; em realismo epistemológico (ou "tese de que existe um mundo independente da mente [e que] na percepção captamos mentalmente qualidades e objetos que fazem parte do mundo"); e, também, em realismo moral, entendido como teoria segundo a qual "há factos morais independentes das nossas crenças ou atitudes", que são "independentes da vontade de legisladores divinos ou humanos", podendo se referir também a uma "perspectiva realista do caráter e conduta humana" (Mautner, 2010c: 632-633).

Na teoria do conhecimento, os termos realismo e idealismo são associados ao debate sobre a diferença entre o mero pensar - considerado característica 
do idealista - e o conhecer (entendido como "ato de apreensão de um objeto pelo intelecto") realista. Pode-se, portanto, dizer que "a maior diferença entre o realista e o idealista é que o idealista pensa e o realista conhece", visto que "para o realista, pensar [é] ordenar conhecimentos ou refletir sobre seu conteúdo [e ele] nunca teria a ideia de considerar o pensamento como o ponto de partida de sua reflexão, pois, para ele, um pensamento só é possível onde há, antes, pensamentos", ao passo que o idealista, visto que "parte do pensamento para ir às coisas", nunca poderia saber "se aquilo do qual parte corresponde a um objeto, ou não" (Gilson, 1935: 88).

Mas já houve, em filosofia, um sentido contraintuitivo e praticamente oposto ao sentido empirista de realismo, pois o que constituiria o real seriam as ideias graças às quais elaboramos nossa relação (simbólica) com o mundo, não as coisas às quais nossas simbolizações cognitivas se referem. Por exemplo, no realismo absoluto do platonismo defendia-se a concepção da "existência transcendente e primordial das ideias gerais ou universais, cujas cópias [seriam] os objetos materiais e sensíveis da natureza". Na mesma direção, a doutrina medieval defendia a realidade dos assim chamados universais, que teriam existência anterior ao surgimento da consciência humana e seriam, portanto, autônomos, isto é, "desligados dos objetos particulares e concretos" (Gilson, 1935: 88).

Tais exemplos do debate filosófico parecem nos mostrar que

não se deveria crer que os filósofos têm sempre ideias muito precisas quando falam de 'realismo' ou quando se dizem 'realistas' [e] mesmo quando têm ideias suficientemente precisas, não é seguro que tenham algo em comum, [embora] esse tipo de dificuldade nunca tenha desencorajado os filósofos que têm tentado, apesar de tudo, propor características globais ou gerais do realismo, [pois] em muitos casos, o que eles parecem ter em vista [é] a ideia de que o que é verdadeiro ou o que existe poderia muito bem ser independente (ou mais ou menos independente) das nossas crenças mais bem justificadas, de nossas preferências mais razoáveis, de nossas teorias mais refinadas e nossos métodos de investigação mais arrojados. (Ogien, 2006: 948-949)

Assim, essa falta de univocidade semântica do termo realismo e a possível indistinção do seu oposto, idealismo - como na doutrina platônica, em que as ideias "são [consideradas] mais reais que os seres individuais e sensíveis, 
que são apenas seu reflexo e imagem" (Lalande, 1972a: 891) -, não impedem que se pense também em alguma forma de realismo aplicada à problemática ética e bioética. É o que veremos ao tratar da possibilidade de um realismo ético (e bioético) na bioética clínica, sobretudo tendo em conta que esta se refere a práticas concretas envolvidas em conflitos e dilemas morais entre atores sociais em interação, como podem sê-lo médicos (ou outros profissionais da saúde) e pacientes.

Outra justificativa para assumir uma postura realista diante da problemática da bioética clínica (e da ética aplicada ou ética prática em geral) pode ser a de que nas próprias ciências humanas já existem um realismo mental e um realismo sociológico. O primeiro defenderia a realidade de estados mentais (como pensamentos, crenças, desejos e intenções), atualmente estudada, sobretudo, pelas neurociências; e o segundo, a realidade dos fatos sociais, em princípio não redutíveis aos primeiros, mas também, em muitos casos, inseparáveis destes, uma vez que os fatos sociais têm a ver com agentes sociais, seus comportamentos e suas percepções. Portanto, pode-se falar em "concepção fraca da objetividade dos fatos sociais", a qual "admite fatos sociais objetivos sem pagar o preço de uma ontologia extravagante", pois considera que "tais fatos têm uma espécie de influência sobre nossas crenças e nossas ações" (Ogien, 2006: 950).

\section{Metabioética realista?}

Com relação à pertinência de se falar em metaética realista e, especificamente, em metabioética realista, uma indicação parece ser dada pelo novo pragmatismo. Resultante da interação do pragmatismo tradicional - "crença de que o significado de uma doutrina é idêntico aos efeitos práticos que resultam de sua adoção" (Blackburn, 1997c: 307) - com a filosofia analítica - processo de análise da linguagem e dos conceitos utilizados pela reflexão filosófica -, o novo pragmatismo é concebido como uma forma de saber resultante da relação entre nossos pensamentos e a realidade objetiva constituída por nossa práxis, ou seja, resulta do vínculo que podemos estabelecer entre conhecimento e ação. Algo, de fato, já percebido, por exemplo, por Kant, que havia postulado o primado da razão prática, referida à capacidade de produzir objetos correspondentes às representações da razão pura (ou teórica) e referida 
também aos objetos do processo de conhecer, pois, uma vez que "na inteligência comum da humanidade, a faculdade de julgar em matéria prática é em todos os aspectos superior à faculdade de julgar em matéria teórica", pode-se dizer que "a filosofia definida como doutrina da sageza apresenta sobre a filosofia como ciência especulativa a vantagem de não ser derivada de mais nada além do puro poder prático de razão, ou seja, da moral" (Kant apud Guillermit, 1995: 16). Em outros termos, a razão prática "não dita apenas ações particulares, governando antes as relações entre ações, desejos e crenças - tal como a razão teórica governa as relações entre crenças e requer algum material específico para sobre ele trabalhar" (Nagel, 1999: 128, destaque do original).

Esse vínculo entre conhecer e agir é possível graças ao papel dos valores em nossa compreensão das verdades lógicas e dos fatos científicos. Isto é, devido à "concepção pragmática da ação" que reúne na abordagem da experiência humana, os "fatores lógico-formais" e os "fatores empírico-materiais" para poder "ultrapassar os esquemas binários" herdados do cartesianismo, uma vez que "a ação não tolera o dualismo entre interesses materiais e valores" e porque "os valores estão incorporados na dimensão racional da ação e governam estratégias para a realização dos interesses materiais" (Calcaterra, 2011: xv).

Uma ajuda para superar o dualismo parece vir do fato de o novo pragmatismo tentar ultrapassar também a posição tradicional da filosofia analítica com relação ao estudo da linguagem, que desconsiderava a sua dimensão performativa (a qual relaciona esquemas conceituais e conteúdos empíricos, isto é, que faz o que diz fazer) e julgava "fatos e verdade como reais, ao passo que os valores seriam meramente emocionais e relativos" (Cormier, 2011: ix).

Um claro exemplo dessa posição pós-dualista do neopragmatismo nos é dado pelo filósofo norte-americano Hilary Putnam, quando destaca o que chama de "colapso da dicotomia entre fato e valor" (2008: 17), tentando mostrar que o conhecimento de fatos sempre pressupõe um conhecimento de valores - o que tornaria fatos e valores inseparáveis - e que os significados envolvidos em "nossas palavras não estão simplesmente no nosso cérebro, sendo antes funções da história das nossas interações com a totalidade do meio ambiente, tanto físico quanto social" (Putnam, 2010: 617). Tal raciocínio 
implicaria, portanto, tentar superar a tradicional dicotomia fato-valor, herdada de uma linha de pensamento que começa com David Hume (1711-1776), se desenvolve com o positivismo lógico e nos impediria de "ver como a avaliação e a descrição estão interconectadas e são interdependentes", que "a própria ciência pressupõe valores" e que os próprios "valores epistêmicos (coerência, simplicidade e similares) também são valores e estão no mesmo barco com os valores éticos, no que diz respeito à objetividade". Em suma, Putnam tenta mostrar que a relação entre fatos e valores não é de separação (como pretende a Lei de Hume), mas de imbricação, pois "um fato é algo que corresponde a uma impressão dos sentidos", e "o conhecimento dos fatos pressupõe o conhecimento de valores" (Putnam, 2008: 14-15, 47, 181).

É com base nessas considerações críticas que podemos abordar a proposta de um realismo na bioética clínica, que veremos a seguir.

\section{Realismo Ético na Bioética Clínica?}

Uma abordagem realista da problemática da bioética clínica (do grego klinikos, referido ao "médico que visita o doente", de klinê, "leito") (Bloch \& Von Wartburg, 1968: 137) é compreensível e justificável. Compreensível porque a problemática da bioética clínica se refere a um conjunto de "atos, fatos e instituições" que se relacionam necessariamente com um "particular concreto" chamado paciente, o qual pode ser entendido como "ente real, concreto e individual onde se manifesta, produz e origina a doença" (Morales, 2008: 74-75). Ademais, pode-se dizer que uma abordagem realista da bioética clínica é justificável com base nas próprias características da primeira ética profissional conhecida, como foi provavelmente a própria ética aplicada dos médicos, norteadora de seu agir profissional e conhecida, historicamente, como ética hipocrática.

De fato, desde o século $\mathrm{V}$ a.C. os médicos partilham uma deontologia (ou ciência dos deveres) que é aplicada aos atos de sua profissão, conhecida como deontologia médica. Tais deveres estão contidos no Juramento de Hipócrates, que compromete o médico a atuar em prol da saúde do doente sob sua responsabilidade e permanece "a referência deontológica fundamental até o século XX" (Hottois, 2001a: 262). Parece, portanto, justificado pensar em um 
realismo da própria ética médica como um todo, inclusive a bioética clínica, em razão das próprias características de sua prática, inseparáveis dos valores que a orientam e da justificativa que a acompanha, que poderá ser cogente ou não e, portanto, justificada ou arbitrária.

\section{'Realismo' metaético?}

Mas dizer que a ética lida com alguma forma de realismo não implica necessariamente dizer que esse realismo constitua também a característica daquela forma de saber teórico conhecido como metaética e considerado uma parte da ética como um todo. Pelo menos se entendermos - como já vimos no início deste ensaio - a metaética stricto sensu, considerada como uma "atividade de segunda ordem em que se investigam os conceitos e os métodos da ética", sem nos preocuparmos diretamente com os problemas práticos envolvidos, ditos de primeira ordem e que concernem "ao que devemos fazer e a como devemos nos comportar" (Blackburn, 1997b: 246). Ou seja, se mantivermos afastado do trabalho analítico qualquer aspecto que possa ser inscrito na categoria chamada realismo, e conservando, portanto, não só uma distinção lógica, mas também uma separação entre problemas de primeira ordem e problemas de segunda ordem, isto é, entre problemas referentes a fatos reais e problemas referentes a representações de fatos, que chamaremos de teóricos (ou logoteóricos), para distingui-los dos problemas práticos (ou técnico-práticos).

Entretanto, essa distinção entre atividades de primeira ordem e atividades de segunda ordem não necessariamente deve ser acompanhada de uma separação entre ordens distintas, pelo menos se entendermos a metaética como um estudo filosófico mais amplo da moralidade, não reduzido à análise conceitual e metodológica, mas que considere também os aspectos referenciais e, sobretudo, os aspectos pragmáticos da linguagem da ética. Um exemplo desses aspectos são os próprios enunciados morais que, como atos linguísticos, têm, além das dimensões denotativa e conotativa, uma dimensão pragmática, graças à qual os enunciados morais se tornam inseparáveis dos referentes (ou fatos) que os atos linguísticos indicam (como podem ser os juízos de aprovação ou recusa sobre determinado comportamento).

Essa dimensão pragmática da metaética deve, por sua vez, ser distinta em outros tipos de estudos dos fatos morais, como aqueles feitos pelas ciências 
humanas e sociais (CHS) - por exemplo, a sociologia, a antropologia, a psicologia (e a psicanálise), a linguística (e a semiótica) - e, eventualmente, pela biologia entendida em seu sentido amplo. A biologia, nesse caso, é compreendida como uma biologia humana ampliada que contempla as antigas categorias de vida, indicadas pelas palavras gregas zoé e bíos, e integra à biologia tradicional as competências cognitivas e técnicas, as quais, vistas como característica ou qualidade emergente do próprio processo evolutivo, remetem ao saber-fazer biotecnocientífico (Schramm, 1996).

Pode-se, portanto, dizer que uma metaética extensa se torna possível quando se parte do pressuposto de que a reflexão filosófica tem preocupações não somente analíticas, como aquelas da metaética tradicional, mas também práticas, como aquelas da ética aplicada e da bioética, nas quais (como já vimos) vige, sobretudo, a razão prática. Isso faz com que entre a metaética e as CHS haja uma espécie de denominador comum, ou (se preferirmos) uma condição de possibilidade para que as várias disciplinas que surgiram historicamente emancipando-se dessa sua alma mater - representada pela filosofia - possam entrar em um tipo de relação empática, isto é, respeitando suas diferenças e pertinências respectivas, mas sem renunciar ao diálogo, quer na forma da interdisciplinaridade (a interseção de disciplinas), quer naquela da transdisciplinaridade (superação das fronteiras disciplinares, situando os estudos "ao mesmo tempo entre, através das diferentes disciplinas e para além de qualquer disciplina") (Catellin, 2014: 210, destaques do original). Em suma, de um ponto de vista pragmático, os problemas metaéticos não são mais necessariamente uma forma de saber separada dos problemas práticos estudados pelas CHS. Ademais, com base nessa concepção ampliada de metaética, não podemos dizer se um enunciado moral é correto ou não, se é racional ou não, e nos comprometermos a agir moralmente sem analisar "se as convicções morais das pessoas são corretas ou cogentes" (Copp, 2006: 6).

Assim, pode-se dizer que a separação (que acompanha a distinção humeana entre fatos e valores na metaética stricto sensu) ${ }^{1}$ é pelo menos questionável,

\footnotetext{
' De fato, a Lei de Hume proíbe a inferência, no campo da moral, daquilo que "deveria ser" a partir daquilo que "é" (Hume, 200I: 509). Essa distinção é diferente daquela introduzida por Moore, que se refere não tanto a deveres (abordados pela deontologia), mas a valores como o Bem (abordados pela axiologia), e denominada pelo autor de falácia naturalista (Moore, 1999).
} 
pois em uma caracterização da metaética em sentido meramente lógico-formal e semântico (certamente indispensável para analisar a linguagem moral) se esquece que os significados da linguagem dependem do uso que deles é feito nos vários jogos de linguagem existentes e que atuam nas formas de vida envolvidas. Esquece-se que os problemas da teoria moral são inseparáveis "dos problemas de descrição das ações, das intenções, das motivações, dos traços do caráter", e que tais vínculos implicam "novas tarefas para a metaética", como a fundamentação e justificação dos princípios, das normas e dos valores morais (que é um problema epistemológico), ou a indagação ontológica e metafísica sobre a natureza dos valores e normas morais:

hoje, metaética é uma categoria da qual os filósofos morais se servem utilmente para qualificar a reflexão crítica que tem por objeto a teoria ética considerada na multiplicidade das suas expressões, inclusive suas referências, implícitas ou explícitas que sejam, de caráter antropológico e metafísico. (Da Re, 2006: 7.339-7.341)

\section{O retorno da filosofia prática}

Feitas essas considerações epistemológicas e metodológicas sobre a pertinência de se aplicar um ponto de vista realista não somente à ética (e à bioética), mas também à metaética (e à metabioética), pode-se acrescentar que, no século XX, uma forma de realismo - que pode ser chamada de realismo moral, pois "afirma que a ética é, ou pode ser, objetiva" (Brink, 1997: 1.261) se manifesta naquele movimento cultural caracterizado pelo retorno do "interesse pelos problemas concretos (...) sob a denominação applied ethics, ou filosofia prática" (Durand, 2003: 73). Esta, a partir dos anos 1960, tenta ultrapassar a antítese entre cultura científica e cultura humanista, que havia sido incorporada pela tradição da filosofia analítica anglo-saxã, a qual produziudurante a primeira metade do século passado - a caixa de ferramentas conhecida como metaética. A metaética será, contudo, entendida stricto sensu como atividade de segunda ordem, isto é, como "análise teórica dos conceitos fundamentais e dos pressupostos ideológicos, independentemente de toda concepção ética particular", ou como "análise do discurso ético [e do] sentido das proposições morais, sem implicação no plano axiológico" (Durand, 2003: 76). E tudo isso sem entrar no mérito das questões pertinentes, referentes às experiências morais concretas, das diversas visões éticas em conflito entre si, e das 
questões da ética normativa, não necessariamente separadas entre si devido a "possíveis comistões com a práxis" (Da Re, 2006: 7.341).

A discussão teórica em ética, elaborada na primeira metade do século $\mathrm{XX}$, se concentra, sobretudo, no problema da relação entre moral e ética, entendendo esta como estudo (ou ciência ou discurso de segunda ordem) da primeira. Isto é, considerando que a principal função da ética seria o esclarecimento dos conceitos utilizados pelas doutrinas morais existentes, assim como uma análise crítica desses conceitos empregados nas argumentações e justificativas morais que leve em conta o seu caráter (de fato uma pretensão) prevalentemente doutrinário.

Historicamente, tal debate teórico é inseparável do contexto cultural em que emergiu a própria metaética, profundamente marcado pelo positivismo e pela exigência de que a própria ética adquirisse estatuto de cientificidade ou pelo menos de objetividade em seus enunciados e deixasse de ser considerada uma construção arbitrária. Ademais, devemos lembrar que, historicamente, a metaética pode ser vista como uma resposta às "tendências que negavam a possibilidade de uma ética normativa e limitavam o papel da ética a ser uma filosofia da moral" ou - de maneira talvez mais modesta - como uma ferramenta reservada ao mero "mundo dos discursos" (Cremaschi, 2005: 12).

É esse conjunto problemático e problematizador que constitui, desde então, o âmbito analítico e crítico em que a metaética de fato atuou antes da transição paradigmática em ética, representada pela emergência da ética prática no começo da segunda metade do século XX. Tal emergência pode ser interpretada como uma transição da problemática e do método da guinada linguística (linguistic turn) (Rorty, 1967), essencialmente preocupada com uma "gramaticalização da experiência" (Gargani, 2006: 9.840), para a guinada pragmática (pragmatic turn), mais preocupada com as práticas sociais e a temática ética e política (Bernstein, 2010). Ou como uma tentativa de construir um "ponto de vista construtivista", capaz de conciliar exigências pragmáticas e a "mentalidade relativista gerada pela crise dos modelos tradicionais de racionalidade", resultantes da filosofia cartesiana, isto é, como um exercício capaz de conciliar a "falibilidade das conquistas teóricas e sua crença na possibilidade de construir hábitos lógicos e comportamentais corroborados 
pela concordância intersubjetiva no raciocínio sobre a experiência" (Calcaterra, 2011: xvi).

Apesar da justificativa aqui apresentada, uma abordagem realista em metaética continua parecendo paradoxal, pelo menos se a entendermos como já vimos - de acordo com as exigências de sua concepção stricto sensu: como atividade racional de segunda ordem que consiste na investigação sobre os conceitos morais envolvidos, seus conteúdos e suas relações lógicas na argumentação moral, a qual deveria ser metodologicamente distinta e separada dos problemas práticos, chamados de primeira ordem, que se referem, por um lado, a tomadas de decisão em situações conflituosas concretas e, por outro, aos princípios ou valores morais a serem adotados para agir corretamente. Por exemplo: para tentar resolver conflitos e evitar suas consequências danosas, como pode ser o caso do sofrimento evitável, abordado, inclusive, pela bioética clínica. Nesse sentido tradicional, o campo da problemática metaética (ou de segunda ordem) não poderia ser confundido com aquele dos problemas éticos práticos (ou de primeira ordem), e tal preocupação em distinguir âmbitos de pertinência diferentes constituiria uma espécie de "higiene lógica" (Palombi, 2003: 60). Essa distinção se aplica também à emergente bioética, como veremos a seguir, apresentando a dialética construída entre as assim chamadas filosofias analítica e continental.

\section{A Superação Construtivista da Oposição entre Analíticos e Continentais em Bioética}

O contexto cultural em que se gesta a bioética na segunda metade do século XX é marcado por um aparente paradoxo entre os chamados analíticos e continentais em filosofia (D'Agostini, 1997) - que pode ser exemplificado pela oposição aqui estabelecida entre metaética stricto sensu e metaética lato sensu. Para Franca D'Agostini, a filosofia analítica se caracterizaria por "fazer uso de formalismos e linguagens 'disciplinadas', requerer argumentações [que sejam] controláveis, e tender, portanto, a tratar questões bastante circunscritas", tendo "um corte prevalentemente conceitual, ou temático" e que "não se ocupa tanto de autores e de textos, mas de conceitos e problemas"; ao passo que a filosofia continental exclui "o uso de linguagens formalizadas", faz uso de "argumentações nem sempre exatamente reconstruíveis", adotando 
um "recorte prevalentemente histórico, ou textual", referindo-se "a autores, a textos, a fases particulares da história do pensamento, a grandes unidades histórico-conceituais (a ontologia antes e depois de Platão; o acontecimento da modernidade; a racionalização na idade moderna etc.)" (D'Agostini, 1997: 58, destaque do original).

Mas tal paradoxo pode ser evitado se abandonarmos o sentido restrito de metaética para subsumi-lo ao sentido amplo (ou lato sensu) aqui indicado pelo adjetivo realista. Como já vimos, essa atitude é, no fundo, um questionamento da própria separação entre problemas de primeira ordem e problemas de segunda ordem, questionamento que pode ser feito também se adotando uma postura metodológica construtivista, a qual se diferencia da tradicional postura - chamada analítica - que é entendida, stricto sensu, não somente como produto de um ponto de vista preocupado em saber fazer distinções, mas também como uma atitude preocupada com a separação dos vários tipos de problemas relativos à ética, a começar pela dissociação entre os problemas de primeira ordem e aqueles de segunda ordem. Entretanto, essa distinção-separação entre ordens e campos problemáticos acaba separando também os problemas de forma (ou de linguagem) daqueles de conteúdo (ou de sentido), que são considerados inseparáveis entre si pelo menos desde o surgimento das ciências das linguagens contemporâneas.

De fato, a distinção-separação atinge a própria relação entre linguagem e problemas concretos, os quais - como veremos - remetem à relação entre enunciados e fatos (ou referentes). Contudo, tal separação, implicada pela metaética tradicional, talvez seja metodologicamente justificada devido à preocupação (positivista e neopositivista) de transformar a filosofia moral (e a filosofia como um todo) em filosofia científica, fundada na lógica e nos "resultados das ciências naturais e exatas", separada de - e até oposta a - uma filosofia "'humanista', que considera determinante a história e pensa a lógica como 'arte do logos' ou 'disciplina do conceito'", e não como mero "cálculo ou computação" (D’Agostini, 1997: 2).

Essa "antítese entre analíticos e continentais reproduz no interior da filosofia a antítese entre cultura científica e cultura humanista", o que constitui uma "turbulência interna da qual a filosofia (...) nunca se libertou 
completamente" (D'Agostini, 1997: 2). Trata-se, em substância, de uma herança da oposição tradicional entre empirismo e idealismo do século XIX, mas que o construtivismo, por um lado, e a hermenêutica e a fenomenologia, por outro, tentaram superar, afirmando, por exemplo, que a distinção não é necessariamente uma separação stricto sensu entre metaética e aquilo "que devemos fazer e como devemos nos comportar" (Blackburn, 1997b: 246).

A abordagem construtivista tem mostrado que, na própria elaboração e produção do conhecimento científico, "não se pode separar o conhecimento construído das finalidades ligadas à ação de conhecer" e que isso depende do "caráter teleológico do julgamento, logo do raciocínio, isto é, [da] capacidade do espírito humano cognoscente de elaborar fins (tells), em relação aos quais se exercerá em seguida a razão (a faculdade de julgar)". Por essa razão, pode-se afirmar que "o ato cognitivo inteiro tem um caráter intencional e, portanto, finalizado" e que "o conhecimento construído por esse ato é ele mesmo finalizado e depende da finalidade que estava na base de sua explicitação" (Mucchielli \& Noy, 2005: 31).

Em outros termos, esse aparente paradoxo - indicado pela antítese entre analíticos e continentais - pode ser superado se estabelecermos uma relação entre o mundo das ideias e o mundo dos fatos que não seja de tipo meramente contrastivo, pois ambos os mundos estão de fato referidos a um terceiro mundo, o qual, por sua vez, se refere ao universo dos valores morais existentes no mundo - que podemos, então, chamar de mundo dos valores - e que são objeto de estudo da própria ética. Ou seja, podemos pelo menos contornar o paradoxo se pensarmos na possibilidade de uma concepção de metaética mais ampla, ou complexa, ainda baseada no método de análise chamado análise conceitual. Esta, considerada necessária à identificação clara dos problemas em pauta, ao lidar com os objetos tradicionais da metaética - essencialmente lógico-formais -, tenta contextualizá-los e integrá-los entre si num todo. E deve, por isso, necessariamente lidar com problemas inerentes a qualquer tipo de linguagem humana, que, além de algum tipo de articulação com o real (dado pela referência), tem patamares distintos - mas não separados - que se entrelaçam num jogo de linguagem e se relacionam - para que haja sentido com o próprio real. 


\section{A necessidade de uma 'análise conceitual'}

Tanto a filosofia da linguagem quanto a psicanálise freudiana mostram que a linguagem tem uma estrutura de superfície "que pode esconder uma lógica profunda, o que pode nos enganar quanto a essa estrutura" (Blackburn, 1997d: 149). Por sua vez, a análise conceitual, entendida como "o processo (ou o seu resultado) de explicar um conceito, uma crença, uma teoria etc., chamando a atenção para os seus constituintes, os seus pressupostos, as suas implicações etc., [que] pode por sua vez servir [para] uma avaliação crítica" (Mautner, 2010d: 57), pode ser vista também como uma tarefa da metaética tradicionalmente entendida, pelo menos se compreendermos esta como uma "investigação teórica a respeito da metodologia e do universo conceitual da ética" (Houaiss \& Vilar, 2001: 1.907).

Mas a metaética pode ser entendida também - em sua nova versão realista como parte de um conjunto mais amplo: como uma reflexão filosófica sobre o que a ética faz e deveria fazer, sobre as razões e as linguagens envolvidas, destacando o "significado dos termos morais; [o] estatuto epistemológico do saber prático e [a] possibilidade, ou não, de uma sua justificação racional; [a] natureza dos princípios e dos valores morais", e devendo, portanto, "enfrentar questões de caráter: 1) lógico-semântico; 2) epistemológico; 3) ontológico e metafísico" (Da Re, 2006: 7.339).

A abordagem realista da ética, aqui delineada, pretende justamente considerar, com a devida atenção, essa lógica profunda inscrita na própria linguagem - inclusive na linguagem moral -, por considerá-la inseparável de uma análise conceitual que tenha uma relação de referência com o mundo e que deve, por isso, não só analisar, mas também situar-se na conflituosidade constitutiva das inter-relações que se dão nas sociedades humanas. Mas tal lógica deve, necessariamente, ser confrontada com o real, entendido como aquilo que em princípio existe independentemente do pensamento humano e suas construções ideais sobre ele (que podem muito bem ser também ilusórias e não dar conta dele).

Entretanto, se não quisermos abandonar o campo da metaética e suas contribuições ao desenvolvimento de uma ética crítica, esse realismo aplicado ao fenômeno da moralidade não deve ser entendido tanto em seus aspectos 
ontológicos ou metafísicos (que se referem àquilo que existe e pode ser em princípio analisado cientificamente ou àquilo que estaria por detrás ou além daquilo que aparece), mas em seus aspectos epistemológico-metodológicos. E isso por considerarmos que "os cânones do raciocínio moral constituem um método confiável para conseguir e acrescer o conhecimento moral", visto que seus enunciados podem ser "verdadeiros ou falsos independentemente das nossas opiniões" e porque seria "possível predicar a verdade ou falsidade dos enunciados que contêm avaliações ou apreciações morais" (Schiavello, 2006: 9.476).

Por todas as razões aqui mencionadas (e que certamente mereceriam ulteriores investigações), manteremos a distinção lógica entre primeira ordem e segunda ordem, aplicada aos fatos morais, mas evitando sua separação e admitindo, portanto, algum tipo de vínculo entre metaética e ética aplicada, em substituição à concepção tradicional de metaética, fundada em sua separação da ética substantiva. Esse é o caso do ponto de vista apresentado, por exemplo, pela filosofia realista atual, que pode ser entendida como constituída por um "realismo crítico (...) segundo o qual o nosso conhecimento do mundo exterior sempre envolve um sujeito, um percepto e um objeto" (Mautner, 2010c: 634), e também como "o melhor quadro teórico para colocar a questão das relações entre linguagem, pensamento e realidade" (Benoist, 2011a: 10-11).

Feita essa longa justificativa da pertinência do realismo em ética, abordaremos, a seguir, a pertinência de uma postura filosófica chamada realista e as possíveis relações que se possam estabelecer entre o realismo ético e a bioética clínica. E também o que podemos entender por fatos na bioética clínica graças às ferramentas da metaética amplamente entendida; o contexto da emergência do paradigma da vida no campo das ciências humanas e sociais; as relações entre ética e metaética na história da bioética; a bioética clínica, suas questões metaéticas e metabioéticas e as condições de possibilidade de uma metabioética realista possivelmente atuante.

\section{Pertinência da Postura Filosófica Realista para a Bioética Clínica}

Existem boas razões para pensar que a postura filosófica dita realista é aplicável à problemática da bioética clínica como um todo, pois, nesta, os 
problemas conceituais e semânticos (que são objeto da metaética) têm um vínculo com a facticidade da conflituosidade moral real, abordada pela ética aplicada em geral, e à qual pertence também a bioética clínica - que certamente lida com conflitos de interesses e de valores, como bem mostra o fato de existirem comitês e conselhos de bioética em muitos hospitais, inclusive no Brasil.

A bioética clínica deve lidar, em primeiro lugar, com a conflituosidade real atuante na prática, algo já destacado, em outro âmbito - a política -, pelo realismo político de Maquiavel, o qual enfocava as relações de força mais do que os eventuais pactos (que serão abordados, por exemplo, por Hobbes no Leviatã e por Rousseau no Contrato Social), e representaria "um pensamento radical da existência em sua inevitável dimensão contrastiva" (Esposito, 2010: 50). Por isso, o realismo político deve partir da constatação da conflituosidade real e intrínseca às inter-relações humanas, que se manifestaria inclusive nas relações políticas.

Ademais, a bioética clínica deve lidar com esse real que se manifesta nas situações conflituosas de seu dia a dia, o que leva à necessidade de agentes morais e responsáveis que sejam competentes para lidar com elas. $\mathrm{O}$ todo devendo ser inscrito - hoje em dia - em um contexto complexo que é, ao mesmo tempo, psicológico, antropológico, sociológico, econômico e ecológico; ou seja, tendo em devida conta dimensões não necessariamente compatíveis entre si, como parece mostrar a atual crise de civilização dita global.

\section{A questão do colapso do consenso em campo moral}

Essa crise global parece patente também em campo moral, pelo menos se pensarmos na curta história da bioética, entendendo-a como uma história dos conflitos entre estranhos morais. Estes, como atores morais, não contam com pressupostos éticos comuns para lidar concretamente com a conflituosidade real (Engelhardt Jr., 1996) e se encontrariam, atualmente, na condição existencial atravessada por "uma diversidade moral insolúvel" e marcada por um "colapso do consenso" - o que não permitiria "vislumbrar no horizonte nenhuma solução para nossas controvérsias" (Engelhardt Jr., 2012: 20).

Aqui não aprofundaremos a questão problemática desse possível colapso do consenso - que na prática acabaria por solapar qualquer possibilidade de 
uma bioética capaz de resolver conflitos concretos - e tentaremos focar nossa atenção nas condições de possibilidade para enfrentar essa difícil questão de outra maneira: condições de possibilidade que podem ser vistas naquilo que a bioética faz - ou deveria fazer - com a sua caixa de ferramentas, a qual incluiria a ferramenta que chamamos metabioética.

Mas, para que possam ser conhecidos, os problemas reais e complexos enfrentados pela bioética precisam, antes, ser entendidos e esclarecidos; ou seja - de acordo com uma distinção proposta por Etienne Gilson (1935) -, os problemas devem ser pensados para ser conhecidos. De fato, essa tarefa faz parte das tarefas tradicionais da metaética, a começar pela análise conceitual, que pode ser considerada sua principal ferramenta para uma análise pertinente do discurso moral, entendido, fenomenologicamente, como "a dimensão originária a partir da qual é possível articular a compreensão de qualquer fenômeno cultural e natural" (Palombi, 2003: 32). A comunicação - ou compartilhamento - desse sentido entre os atores sociais em conflito envolvidos, e que queiram chegar pelo menos a um acordo, isto é, ir além (se possível) da mera constatação factual, como pode ser aquela do colapso do consenso, também é uma dessas tarefas.

Em realidade, esse é o principal objetivo, ao mesmo tempo ético e político, do pluralismo, baseado na tolerância, e que surge em época contemporânea a partir do final do século XIX, para permitir o desenvolvimento de

sociedades compostas por indivíduos e grupos livres para não partilhar as mesmas convicções culturais, morais, políticas, religiosas e filosóficas, mas, no entanto, desejosos de viver em conjunto e de, para esse efeito, acordar entre si um conjunto de regras que assegure a viabilidade de sociedades desse tipo. (Hottois, 2003c: 524)

Assim, mesmo admitindo (por absurdo) esse colapso referido ao consenso, isso não impede - como já indicamos - que exista a possibilidade de se encontrarem acordos práticos (ou pragmáticos) entre atores em conflito, pois já o termo, bastante vago, consenso (do latim consensum, que significa propriamente compartir o mesmo sentido), empregado na expressão de Engelhardt "colapso do consenso" (2012: 20), permite pensar (e eventualmente conhecer) tal possibilidade. 
A expressão colapso do consenso pode ser entendida de duas maneiras diferentes. Num primeiro sentido, pode estar referida a uma incompatibilidade a priori entre sistemas morais diferentes e, num segundo sentido, pode ser entendida como incompatibilidade a posteriori. Ou seja, o "colapso" pode ser o resultado de uma incongruência de princípio (ou lógica), pois partilhar o mesmo sentido (como diz a semântica da palavra latina consensus) seria uma condição necessária de um processo comunicativo entre conflitantes. Mas o consenso, embora não dado a priori, pode eventualmente ser construído a posteriori, isto é, no momento do confronto entre sistemas diferentes, e isso para tentar elaborar um sentido compartilhado e considerado necessário para a solução do conflito em pauta. O contrário sendo também possível, pois podemos partir de um consenso e acabar, por alguma razão não conhecida de antemão, num desacordo que indicaria esse colapso do consenso indicado por Engelhardt (2012).

Em outros termos, podemos admitir a existência de um colapso do consenso com relação a crenças, que são construções de primeira ordem (como podem sê-lo as várias crenças morais e as escalas de valores existentes no mundo atual), sem, com isso, sermos obrigados a inferir que exista, consequentemente, o mesmo tipo de colapso entre construções de segunda ordem, que podem muito bem dialogar entre si. Ou seja, mesmo admitindo-se que esse colapso seja algo existindo no real, demonstrável com base na conflituosidade existente (como na guerra), isso não impede a possibilidade de se estabelecer algum tipo de relação, diferente da mera incompatibilidade lógica ou semântica, e que pode ser chamada de pragmática (como os acordos de paz após uma guerra ou os acordos preventivos de uma guerra). Essa pode ser inclusive a tarefa (embora indireta) de uma reflexão crítica sobre os fatos abordados pela bioética clínica que seja mais ampla do que aquela da metaética tradicionalmente entendida, pois uma concepção extensa de metaética permite que esta seja vista como inseparável de seu contexto conflituoso real e das várias tentativas de construir, se não consensos, pelo menos acordos (por exemplo, sobre um sofrimento evitável). Tal pode ser o caso de uma reflexão que parta da análise conceitual dos termos e categorias utilizados, assim como de uma análise lógica dos argumentos em campo durante as deliberações, para tentar identificar o que tanto a linguagem 
do senso comum como as linguagens especializadas (como aquelas das éticas aplicadas) escondem em sua lógica profunda, em suas margens e não ditos, o que deverá ser de fato desconstruído e reconstruído para que a terapia possa funcionar na prática.

Tudo isso pode ser visto como um desafio para a metaética em geral e a fortiori - insistindo na utilização deste neologismo - para a metabioética, entendida como análise de segunda ordem dos enunciados e juízos da bioética e referida ao pluralismo normativo vigente em bioética. Mas pode se tornar - como já vimos - um desafio incontornável se a metabioética for entendida como um campo da ética não somente distinto, mas também separado das relações contextuais e do mundo, as quais participam da criação do sentido, inclusive de tipo moral, no mundo.

No caso específico da bioética clínica, pode-se dizer que o principal objetivo de uma possível metabioética consistiria em uma análise crítica dos conceitos e argumentos envolvidos nos fenômenos morais. Tal análise seria, assim, considerada necessária na procura de solução para os conflitos que podem surgir na prática clínica, a qual pode, assim, ser caracterizada pela qualidade das relações humanas que se estabelecem entre os dois tipos de atores chamados - de acordo ainda com a terminologia de Engelhardt Jr. (1996) agentes e pacientes morais.

\section{A questão da análise racional e imparcial}

Essa qualidade das inter-relações humanas em uma sociedade que se concebe como pluralista depende das tentativas práticas de solução da conflituosidade que, por sua vez, é intrínseca a tais inter-relações.

Nessas tentativas, um dos métodos (ou caminhos) a serem adotados consiste em imaginar um ponto de vista ideal, identificado com um hipotético espectador racional e imparcial, chamado também de observador ideal, tido como supostamente capaz de obter uma avaliação abrangente do todo (e de seu caráter conflituoso) que possa ser considerada objetiva, isto é, livre de preconceitos e das consequências de um envolvimento emocional, não controlado racionalmente, que poderia enviesar o juízo, tornando-o parcial. Foi a consideração dessa possibilidade - como já observamos também para o 
neopositivismo - que levou ao projeto de uma ética objetiva e científica, como aquela visada pela filosofia analítica da primeira metade do século XX.

Se olharmos a história da ética do século XX, esse papel analítico e imparcial parece ter sido aquele da metaética, que pode ser entendida também como uma semiótica das questões de forma e de conteúdo referentes ao uso das ferramentas da ética, visto que uma semiotização desse tipo pretende descrever e entender os conflitos e, mediante esse entendimento analítico - que pode ser compartilhado ou não pelos agentes e pacientes morais -, propor soluções normativas (axiológicas ou deontológicas) capazes de orientar sua solução. Esse poderia ser o papel de uma semiótica da ética - a ser pensada e desenvolvida como uma "ciência do valor" (Fontanille, 2007) - ou, mais precisamente, de uma "semiótica das práticas éticas", interessada mais "em analisar práticas do que textos" e considerando o sujeito humano não mais como mera "posição sintática de uma narrativa fechada", mas sim como "subjetividade plena em formação e que se questiona"; em suma, uma semiótica da ética entendida como uma forma de saber que se ocupa das "relações entre o sujeito concebido como produto discursivo e o sujeito [entendido] como pessoa que age no mundo" (Dondero, 2008: 5).

Entretanto, o propósito neste ensaio é mais modesto, pois aqui pretendemos analisar um aspecto específico dessa problemática complexa, representada por uma possível semiótica da bioética, tentando mostrar - para começar-que tanto o conceito de imparcialidade quanto a justificativa para separar a metaética da ética descritiva e da ética normativa são ainda objetos de controvérsias. No entanto, também cabe mostrar que essa controvérsia pode, de algum modo, ser superada (ou pelo menos contornada), mantendo-se a distinção entre tais âmbitos, sem que isso implique, necessariamente, sua separação, pois tal distinção depende, em última instância, daquilo que entendemos por linguagem, suas características e funções.

Esse percurso possível tem antecedentes, pois tal tipo de procedimento analítico, inseparável de seus desdobramentos práticos, é umas das conquistas da própria filosofia da linguagem - a partir do "segundo Wittgenstein" (Wittgenstein, 1953, 1990), preocupado essencialmente com o papel das atividades linguísticas sobre as ações e as vidas das pessoas - e da linguística do século XX. Esta, pelo menos desde a teoria dos atos de fala de Austin (1962), 
sabe que não há mais consenso sobre a pertinência e legitimidade de separar o significado e o uso da linguagem nos jogos de linguagem adotados, assim como não há mais consenso sobre a "dicotomia entre fatos e valores" (Putnam, 2008), a qual levava não só a distinguir, mas também a separar, descrição e prescrição. E isso é possível porque haveria descrições de fatos que contêm significados morais e avaliações morais que encerram conteúdos referentes a fatos, como pode ser o caso dos nossos juízos referidos aos conflitos morais em que estamos envolvidos. Em suma, nesse contexto realista, a própria metaética parece instada a se ocupar não somente da análise conceitual e da lógica dos enunciados e discursos morais - análise certamente necessária, mas não suficiente, de um fato moral -, mas também da relação entre tais conceitos e os enunciados que os contenham, assim como da relação dessa linguagem com seus referentes concretos, como podem sê-lo os conflitos reais.

Entretanto, relações devem, ainda, ser referidas àquilo que Merleau-Ponty chamou de "a carne" do mundo, entendida "não como fato ou somatório de fatos, mas como lugar de uma inscrição de verdade", em que "meu corpo é feito da mesma carne do mundo [e], ademais, essa carne de meu corpo faz parte do mundo", pois "ele a reflete, ele se apossa dela e ela se apossa dele" (MerleauPonty, 1964: 171, 297, destaque do original). Ou seja, essa "carne" se inscreve no ethos vigente, representado pelas ações e intenções dos agentes morais, assim como pelos motivos e pelas particularidades desses agentes que afetam (ou podem afetar) os pacientes morais - destinatários dos atos dos primeiros -, o que torna os juízos éticos uma espécie particular de fatos. Ademais, não se pode esquecer que tais fatos se inscrevem também - de acordo com o ponto de vista da fenomenologia - no "mundo social prático, onde ocorrem relações intersubjetivas" (Depraz, 1997: 124).

É nessa espécie particular de fatos que se destacam os fatos da bioética clínica, que veremos a seguir, inscrevendo-a em seu contexto cultural.

\section{Os Fatos da Bioética Clínica e seu Contexto Cultural}

Os fatos da bioética clínica podem ser vistos como eventos que se referem à conflituosidade moral "em todos os cenários institucionais" onde se realize alguma prática clínica, e cujo objetivo principal é constituído pela 
"[promoção do] desenvolvimento do campo da ética clínica e assessoria ética", por meio de um "enfoque interdisciplinar". 2

Nessa concepção, ao abordar a conflituosidade moral, relacionam-se essencialmente três aspectos:

1) Um aspecto referente ou fato real, constatável objetivamente e representado pelos conflitos morais reais inscritos nas inter-relações entre médicos (e demais profissionais da saúde) e pacientes (e seu entorno familiar ou comunitário) na prática clínica.

2) Uma competência ética específica, em princípio por parte dos agentes morais que tenham alguma familiaridade com a caixa de ferramentas da ética aplicada e da bioética e as apliquem concretamente, por exemplo, na assessoria em ética (como no caso de um consultor em bioética de um hospital) e na participação em algum dispositivo de ética ou bioética institucional (como membro de um comitê de ética hospitalar, de um conselho ou de uma comissão de bioética ou de um comitê de ética em pesquisa). Tal participação pode ser considerada necessária, por exemplo, quando se trata de resolver, de maneira profissional, conflitos morais que dificilmente podem ser resolvidos espontânea e intuitivamente, isto é, sem um saber específico, como o da bioética, o qual se relaciona - de acordo com as exigências da interdisciplinaridade e/ou da transdisciplinaridade amplamente reivindicadas por bioeticistas - com pontos de vista, paradigmas, métodos e problemas de outras formas de saber e de saber-fazer envolvidas.

3) O contexto antropológico e sociológico de pluralismo moral, supostamente vigente nas sociedades complexas e democráticas contemporâneas, nas quais devem ser enfrentados conflitos de interesses e de valores para que os agentes e pacientes morais envolvidos tentem resolvê-los da melhor maneira possível.

A relação entre essas três dimensões pode ser vista como complexa, pois fatos, competência específica e contexto podem ser distintos - como objetos de estudo de várias disciplinas - mas não separados, porque estão entrelaçados e formam um conjunto em que as três dimensões devem ser pensadas, ao

${ }^{2}<$ www.ethics2012.org.br/conferencias.php>. Acesso em: 9 out. 2013. 
mesmo tempo, como distintas e relacionadas, ou seja, numa espécie de tensão dialética sem fim. Se excluirmos essa tensão dialética entre tais dimensões, teremos inevitavelmente - como pretende Engelhardt (2012) - o colapso de um possível consenso ou acordo. Parece, portanto, que tal dialética demanda uma reflexão crítica sobre os fatos contextualizados, a qual, por sua vez, demanda, muitas vezes, também uma análise conceitual dos termos e categorias utilizados, ademais de uma análise lógica dos argumentos em campo nas deliberações, pois tal análise conceitual serve para pensar corretamente, isto é, para identificar, com clareza, o problema e tentar conhecê-lo em seus aspectos morais pertinentes e, a partir disso, eventualmente resolvê-lo de forma prática mediante algum acordo compartilhado.

Mas essa análise conceitual, como já vimos, é considerada, tradicionalmente, tarefa da metaética, que pode ser entendida - de acordo com o sentido dos dicionários - como:

1) uma "investigação teórica a respeito da metodologia e do universo conceitual da ética, em oposição às reflexões morais que envolvem questões empíricas, como o modo correto de ação ou a reta disposição de caráter no comportamento cotidiano" (Houaiss \& Vilar, 2001: 1.907), isto é, como um discurso de segunda ordem aplicado aos fatos de primeira ordem, representados pelas crenças morais;

2) uma reflexão filosófica mais abrangente e que pode ser vista como distinta tanto da ética descritiva quanto da ética normativa, porque a ética descritiva "utiliza os resultados fornecidos pelas ciências humanas, a antropologia cultural, a etnologia, a sociologia, a estatística etc., para identificar [os] comportamentos considerados de fato justos ou concretamente praticados, ou estabelecidos por determinados códigos morais [em] ordenamentos jurídicos particulares" e a ética normativa se ocupa das "diversas modalidades de argumentação moral e de formulação dos juízos morais, [assim como da] identificação das normas morais" (Da Re, 2006: 7.339).

Entretanto, essa análise conceitual se inscreve-considerada seja no sentido 1, seja no sentido 2 - em um contexto cultural preciso, constituído hoje pela emergência do "paradigma da vida", produto de um "pensamento vivente" 
e resultante do "cruzamento entre vida e história - constituído pela política" e que produziu a biopolítica, entendida como forma de saber que apresenta efeitos performativos sobre a vida humana - pois, graças a tal pensamento vivente, a vida ter-se-ia tornado "objeto de práticas políticas destinadas a transformá-la e, portanto, [a torná-la] inevitavelmente, matéria de conflitos" (Esposito, 2010: 10-11).

\section{O contexto representado pela emergência do paradigma da vida e o caso da Italian theory}

De um ponto de vista crítico, o tipo de relação existente (ou desejável) entre metaética, ética descritiva e ética normativa, assim como a relação específica entre ética e política, inclusive entre biologia, bioética e biopolítica, foi objeto de intensos debates ao longo do século XX (Bazzicalupo, 2010), produzidos no contexto de uma nova guinada epistemológica, representada pela emergência do paradigma da vida. Tal paradigma sucede - mas também integra - os conteúdos da guinada linguística (linguistic turn) da filosofia analítica anglo-saxã do século XX, embasada no paradigma da linguagem, que já havia produzido a linguística geral e a semiótica (ou semiologia) entre o final do século XIX e o começo do século XX, com Charles Sanders Peirce (mais conhecido como um dos fundadores do pragmatismo, entendido como uma filosofia que vincula crenças e ações) e Ferdinand de Saussure (considerado o fundador do estruturalismo, para o qual o sentido dos fenômenos humanos só se dá na estrutura formada por suas inter-relações).

Tais debates apresentaram, inicialmente, um cenário em que se destaca um traço negativo e desconstrutivo, uma vez que a discussão "deve se limitar a desmontar seus conceitos, ao invés de criá-los", e "a tarefa atual da filosofia parece ser aquela, autocrítica, de refutar suas próprias pretensões hegemônicas frente a um Real colocado fora de seu alcance" (Esposito, 2010: 3-12), pois tal desconstrução (ou pars destruens) é considerada condição necessária para uma possível reconstrução por vir.

Esse é, por exemplo, o caso da recente Italian theory, a qual tem uma longa gestação no pensamento da esquerda extraparlamentar italiana e começa nos anos 60 do século XX com o debate entre gramscianos - que salientavam a importância do intelectual dito orgânico - e defensores do operaísmo, os quais 
se distinguiam da figura do intelectual orgânico e interpretavam seu tempo como um tempo de crise e de divisão (Calabrò, 2012). Na avaliação de um dos seus representantes, tal teoria se afirma, em âmbito internacional, no começo do século XXI com a preocupação de "entrar em relação, analítica e crítica, com os traços dominantes do nosso tempo" e sair dos impasses do "pensamento contemporâneo, bloqueado na celebração pós-moderna de seu próprio fim para reencontrar uma alavanca para voltar a funcionar de maneira afirmativa" (Esposito, 2010: 3-12).

Talvez o principal produto desse movimento seja o destaque conferido, no âmbito da política inscrita no mundo vital, à problemática chamada biopolítica. Surgida oficialmente com a metodologia genealógica de Foucault, entendida no duplo sentido de poder de vida e poder de morte, a biopolítica é aplicada tanto às formas de saber-fazer científico, produzidas por "uma transformação na maneira como o próprio corpo é investido pelas relações de poder", quanto às formas de governar a vida das populações e aos dispositivos graças aos quais "o corpo [se encontra] diretamente imerso em um campo político [e] as relações de poder operam uma captura imediata" (Foucault, 1976: 28-30).

O termo governamentalidade foi introduzido por Foucault em 1978 em substituição ao termo poder, para indicar as maneiras de governar constituídas pela

articulação entre formas de saber, relações de poder e processos de subjetivação (...) sobre sujeitos e com a ajuda de saberes [que, no entanto,] permitem que formas dadas de subjetividade ou saberes determinados [funcionem] como resistências a determinados procedimentos de governamentalidade [pois] pode-se resistir a formas de governo [recusando] ser governado desta ou daquela maneira, e opor a formas de saber ou de subjetividade articuladas sobre procedimentos de governo dados outros discursos teóricos ou relações consigo. (Gros, 1998: 84, destaques do original)

Como explicou o próprio Foucault (2004a: 111-112),

[por] "governamentalidade" entendo [em primeiro lugar] o conjunto constituído pelas instituições, os procedimentos, análises e reflexões, os cálculos e as táticas que permitem exercer essa forma bem específica, embora muito complexa, de poder que tem como alvo principal a população, como forma maior de saber a economia política, 
como instrumento técnico essencial os dispositivos de segurança. Em segundo lugar (...) entendo a tendência, a linha de força que, em todo o Ocidente, não parou de levar (...) para a preeminência desse tipo de poder que se pode chamar "governo" sobre todos os outros: soberania, disciplina, e que levou, por um lado, ao desenvolvimento de toda uma série de aparelhos específicos de governo [e por outro lado] ao desenvolvimento de toda uma série de saberes. Por fim, creio que por "governamentalidade" deveríamos entender o processo, ou, de preferência, o resultado do processo pelo qual o Estado de justiça da Idade Média, que se tornou, nos séculos XV e XVI, Estado administrativo e, pouco a pouco converteu-se [em Estado] "governamentalizado".

Historicamente, a gestação da problemática biopolítica, entendida como "a filosofia do progresso positivista [e] como projeto de aplicação da ciência a todos os campos do saber e da vida", se dá a partir da segunda metade do século XIX, que é quando surge também o neologismo biocracia para indicar um "projeto de reorganização social e política baseado nos saberes biológicos, que fornecem normas e princípios para comportamentos racionais e socialmente adequados" (Bazzicalupo, 2010: 23-24).

Mas é a partir de uma desconstrução da própria obra de Foucault que a reflexão crítica da Italian theory é desenvolvida, inicialmente, por Giorgio Agamben, que amplia e problematiza o ambíguo conceito foucaultiano de biopolítica. Para fazer isso, Agamben inscreve o conceito de biopolítica na "dupla categoria fundamental da política ocidental [que] não é aquela amigoinimigo, mas [aquela de] vida nua-existência política, zoé-bíos, exclusãoinclusão", pois considera que a "política existe porque o homem é o vivente que, na linguagem, separa e opõe a si a própria vida nua e, ao mesmo tempo, se mantém em relação com ela numa exclusão inclusiva" (Agamben, 2002: 16).

Em seguida, essa reflexão é desenvolvida por Roberto Esposito (2002), para quem o conceito de biopolítica estaria vinculado de fato ao paradigma imunitário que o precede e que teria grande poder heurístico, pois constituiria "um dos primeiros temas de alcance global na filosofia do novo século" (Esposito, 2010:5) e uma das condições de possibilidade de um "pensamento vivente" capaz de dar conta de uma possível "biopolítica afirmativa". Isso graças à detecção de "um possível dispositivo 'normativo' [capaz de] conjugar as exigências [de] proteção da vida e aquelas da salvaguarda do conflito a ela inerente", 
visto que sem essa salvaguarda não seria possível dar conta do "nó crucial entre proteção e negação", isto é, do fato de que "a vida pode ser protegida contra aquilo que a nega somente por meio de uma ulterior negação" (Calabrò, 2012: 113).

O debate sobre a emergência do paradigma da vida e seus desdobramentos é intenso e contraditório, seja porque tal emergência representaria "uma 'virada', sucessiva àquela linguística" (Esposito, 2010: 10), ocorrida um século antes, seja porque o paradigma da vida já se delineia antes da virada linguística (com Darwin), ou ainda porque, quando surge o pragmatismo norte-americano, com Peirce, James e Dewey, os dois paradigmas passam a coexistir.

Os pragmatistas compartem a ideia de que a filosofia moral é mais um movimento concreto do que um mero conjunto de problemas morais analisados pelas disciplinas da linguagem (e que se indica pelo termo metaética), assim como têm a convicção de que o próprio pensamento produz crenças que se explicitam em regras ou em hábitos que, por sua vez, produzem "os efeitos que podemos conceber como tendo implicações práticas", sendo que a concepção "que temos desses efeitos constitui a totalidade de nossa concepção desses objetos" (Putnam, 1997: 1.180).

Entretanto, aqui não aprofundaremos esse debate. Lembramos apenas que, para alguns, seu principal resultado metodológico foi - apesar da aparente subsunção do antigo paradigma da linguagem ao mais recente paradigma da vida - tornar pertinente "a identificação da especificidade da linguagem moral [que] permite (...) justificar a ética como um saber autônomo", distinto de outros saberes (Da Re, 2006: 7.340).

Com efeito, não é que com o surgimento (ou o ressurgimento) do paradigma da vida desapareça o paradigma da linguagem (como uma apropriação incorreta da terminologia de Thomas Kuhn poderia sugerir), considerando, por exemplo, os dois paradigmas como sequenciais (um paradigma substituindo o outro). Os dois paradigmas de fato coexistem numa longa "transição paradigmática" (que é outra categoria de Kuhn) em que coabitam os dois tipos de saberes, vinculados a tais paradigmas e vinculados entre si. Dito de outro modo, o que parece estar acontecendo atualmente é a possibilidade - aparentemente confirmada por fatos como o crescente interesse pela biopolítica, inclusive no 
campo da saúde - de pensar uma autonomia da ética - supostamente adquirida quando a ética se tornou uma "ciência objetiva" graças à incorporação das ferramentas analíticas das ciências da linguagem. Tal possibilidade parece se dever à relevância - dada pela corrente analítica já a partir dos estudos de Moore (1999), para quem não se podem confundir conceitos e fatos morais, ou aquilo que "é" e aquilo que "tem valor", ou "Bem", sob pena de se cometer uma "falácia naturalística" - atribuída à assim chamada imparcialidade (ou isenção), representada pela imagem do observador racional e imparcial.

Mas essa imagem da imparcialidade, como vimos também, visa à objetividade dos fatos analisados pela componente descritiva e compreensiva da ética, entendida essencialmente como garantia de sua cientificidade. Esta, por sua vez, pode ser vista como condição necessária para a formulação de enunciados morais - ou juízos - que pertencem à sua componente normativa, a qual constitui - para utilizar uma metáfora da linguística aplicada por Saussure ao signo linguístico - a outra face do juízo moral, o qual leva a uma ação que poderá então ser julgada correta ou incorreta "se, e somente se, um observador ideal a aprovar" e que pode ser formulada com a proposição " $P$ é verdadeira se, e somente se, $S$ (um observador ideal) acredita que $P^{\prime \prime}$ (Mautner, 2010e: 539). Em outros termos, o fato moral resultante é constitutivamente coformado - de acordo com a abordagem pragmática já apresentada - pelo sentido resultante de fatos morais objetivos em exame e sua inferência normativa orientadora da ação a ser realizada.

Entretanto, esse tipo de proceder pode ser questionado (como de fato acontece), pois o referimento a um observador racional e imparcial $S$ é considerado, por alguns, como ferramenta necessária para enfrentar os fatos morais concretos (i.e., as práticas e experiências conflituosas concretas) e os vários sistemas de valores vigentes e em conflito entre si, e que, por isso, "requerem um esforço de esclarecimento e de lapidação terminológica" (Da Re, 2006: 7.341). Mas pode ser considerado também como um ponto de referimento demasiado abstrato, pois $S$ não é suficientemente caracterizado para se tornar elemento pertinente e legítimo de um juízo plausível.

O conceito de imparcialidade e sua pertinência como princípio metodológico em ética, assim como o problema da legitimidade de separar ética normativa 
e metaética, caracterizando esta "em sentido puramente formal e de análise semântica" (Da Re, 2006: 7.341), é ainda objeto de discussão dentro da própria filosofia moral de tradição analítica. A partir da segunda metade do século XX, graças às reflexões filosóficas do "segundo Wittgenstein" - que teria produzido em filosofia "uma revolução linguística" ou "guinada pragmática", comparável à "guinada copernicana de Kant" e consistente no método "terapêutico" de "suprimir aqueles problemas filosóficos que se originam de um uso incorreto da linguagem, separado do contexto da vida 'por uma interpretação errada de nossas formas linguísticas'" (Lenk, 2005: 13-14) - e de seus seguidores, como Elisabeth Anscombe ([1958] 1981a), não há mais consenso sobre a pertinência e a legitimidade de separar o significado linguístico e o uso da linguagem nos jogos de linguagem efetivamente em ato. E isso vale, inclusive, nos debates metaéticos da teoria moral (como estamos tentando mostrar). Por isso se costuma - desde essa guinada representada pelo pragmatismo metodológico wittgensteiniano - falar em atos de fala, distinguindo, nestes, atos locutórios ("atos de dizer"), atos ilocutórios ("o que se faz ao dizer") e atos perlocutórios ("o que se produz ao dizer") (Blackburn, 1997a: 29), que podem ser considerados todos como fatos morais, inscritos no real, embora talvez de forma diferente em cada caso, uma vez que o ato de dizer (por exemplo, fazendo uma promessa ou um juramento) se torna um fato que produz um efeito (como realizar a promessa feita) graças ao ato de prometer. Mas isso tem duas implicações existenciais importantes, pois prometer implica se comprometer a cumprir o prometido (sob pena de sanção, inclusive de tipo jurídico no caso do juramento), o que tem consequências práticas para os envolvidos - que podem ser consideradas boas ou ruins por quem as vivencia e, sobretudo, para o espectador dito imparcial.

Tampouco há consenso sobre a pertinência e a legitimidade de separar, no campo da ética aplicada, descrição e prescrição - apesar de devermos em princípio continuar distinguindo-as por uma razão lógica -, visto que existiriam descrições de fatos que contêm significados morais e avaliações morais que encerram conteúdos referentes a fatos que são sempre, como fatos, algo concreto, vivido. Como sentenciou o próprio Wittgenstein (1990: 53), “[são] necessárias, para estabelecer uma prática, não só regras, mas também exemplos. As nossas regras têm lacunas e a prática tem de falar por 
si mesma". Em outros termos, de acordo com essa crítica interna à própria tradição analítica, os problemas abordados pela teoria moral são inseparáveis das descrições das ações, das intenções, dos motivos e dos traços de caráter do agente moral envolvido, o que a torna uma espécie de filosofia analítica dos casos concretos. Sem esquecer "o papel que as emoções têm de nos esclarecer sobre questões de importância ética", podendo-se até dizer que estas teriam "uma função cognitiva", obrigando-nos a "refletir" sobre elas como um componente importante dos próprios fatos éticos (Nussbaum, 2009: xvi).

\section{A necessidade do ponto de vista 'complexo' sobre a moralidade}

Tudo isso que acabamos de apresentar nos leva à proposta de integrar os vários aspectos já descritos no que chamaremos de ponto de vista complexo sobre o fenômeno da moralidade, o qual distingue seus componentes constitutivos, mas sem separá-los.

A principal consequência operativa da aplicação desse ponto de vista complexo, quando aplicado aos fatos morais, é que não podemos mais separar metaética, ética descritiva e ética normativa. Apesar disso, temos que saber pelo menos distingui-las, para não confundir âmbitos que têm também identidade própria (analisada, por exemplo, por disciplinas específicas), embora estejam relacionados entre si devido à vigência do paradigma da vida. Tal paradigma funciona como o contexto real mais amplo em que tais âmbitos específicos se relacionam, e inclui, portanto, os fatos de linguagem, que podem ser considerados elementos do paradigma da linguagem, o qual pode, por sua vez, ser entendido como um subconjunto do paradigma da vida referido ao Homo sapiens.

Assim, parece que, do ponto de vista metodológico, saber "distinguir sem separar, e juntar sem confundir" (Schramm, 2010a: 85) - a imagem síntese do método da complexidade proposto por Edgar Morin (1990: 104), para quem "os princípios do pensamento complexo serão necessariamente princípios de disjunção, de conjunção e de implicação" - é o caminho a trilhar para que se possa combinar: 1) a correta consideração da diversidade tanto das morais como das éticas vigentes (que não representam necessariamente universos coextensivos) que caracterizam o pluralismo contemporâneo de fato; 
2) a sua utilização como dispositivos analíticos e normativos pela prática clínica institucionalizada; e 3) a consideração da bioética clínica como possível foro no qual seja possível construir um diálogo interdisciplinar (ou transdisciplinar, como preferem alguns) entre os vários saberes e as competências específicas envolvidas (Schramm, 2010b).

Esse caminho é certamente um desafio para muitos profissionais, a começar por aqueles que trabalham no campo da saúde e, em particular, da clínica médica. Não somente do ponto de vista da bioética entendida como ética prática, referente à solução concreta dos conflitos do dia a dia da prática clínica, mas também do ponto de vista de uma possível metabioética (utilizando este neologismo que pode certamente ser criticado, como, aliás, já aconteceu com o próprio neologismo bioética nos anos 70 do século XX) (Mori, 1994), entendida como uma metaética aplicada às práticas inscritas num contexto caracterizado pela vigência simultânea do paradigma da linguagem e do paradigma vitalista. O campo complexo da bioética clínica, ao qual a metaética se aplica, inclui - em sua dimensão descritiva e compreensiva - a análise de conceitos, valores e normas envolvidos, assim como uma avaliação da força argumentativa (ou cogência) utilizada para justificar as tomadas de decisão normativas nas situações moralmente problemáticas, e que são vivenciadas nos casos concretos (ou exemplos, na terminologia de Wittgenstein). Ou seja, a bioética clínica utiliza ferramentas dos dois paradigmas.

É esse tipo de desafio que costuma enfrentar a metaética, que, historicamente, pode ser considerada como um dos principais contributos da filosofia analítica ao campo do saber moral, mas que parece instada, atualmente, a se ocupar também das relações entre atos morais, fatos morais e suas representações. Isso se deve à complexificação crescente da problemática ética, a qual adquire cada vez mais uma identidade interdisciplinar (em razão dos vários saberes nela atuantes) e transdisciplinar (visto que seus objetos, representados pelos conflitos, atravessam as fronteiras entre disciplinas).

A seguir, abordaremos, rapidamente, uma parte histórica (ou diacrônica) da relação entre bioética e metaética (aqui também identificada como metabioética) e uma parte sincrônica, relativa à própria pertinência desse tipo de análise conceitual no âmbito da bioética clínica. 


\section{As Relações entre Ética e Metaética na História da Bioética}

De acordo com o bioeticista italiano Maurizio Mori (2011), a bioética, nascida oficialmente nos anos 1970 como a mais importante forma de ética aplicada, parece ter estado na origem de um declínio da tradicional metaética, vigente na ética ocidental desde o começo do século XX - sobretudo na tradição anglo-saxã - e voltada essencialmente para a análise do significado dos termos morais e a avaliação dos argumentos e da lógica subjacente ao discurso moral.

Como explica Mori (2011: 53), os críticos "reconheciam a importância da metaética" e sua "relevante contribuição teórica", inclusive porque instava o filósofo moral a "colocar à disposição [suas] capacidades 'técnicas' adquiridas com o estudo da metaética", o que poderia ter a consequência social desejada de "fazer crescer a consciência civil". Isso porque "a análise lógica dos termos e das inferências, aplicada com rigor aos problemas da vida real", permitiria enfrentar tais problemas com "maior grau de racionalidade e imparcialidade".

Em particular, o reconhecimento da metaética como ferramenta cognitiva pertinente e legítima pressupunha "abandonar a ideia de que a análise dos problemas concretos [implicaria] necessariamente a prevalência das paixões particulares e dos interesses privados sobre a atitude imparcial e racional". Nessa perspectiva, o bioeticista se tornaria um profissional que

teria não somente a oportunidade (a permissão), mas também o dever de examinar sejam problemas gerais (classes de casos), sejam casos concretos específicos (à beira do leito do doente), porque, com seu trabalho filosófico e intelectual, teria dado uma contribuição importante ao crescimento civil da sociedade. (Mori, 2011: 53)

Em termos diacrônicos, pode-se dizer - como já lembramos - que no panorama da história da cultura contemporânea o surgimento da bioética parece marcar a superação da tradicional oposição entre as vertentes analítica e continental em filosofia, denominações que hoje podem ser vistas como a simplificação de um processo complexo de "dois percursos paralelos, que se cruzam às vezes, mas muitas vezes para descobrir novas razões para a divergência" (D'Agostini, 1997: 59).

No primeiro percurso, podemos identificar aquele que corresponde à tradição que começa com o filósofo e psicólogo Franz Brentano (1889), que pode 
ser considerado o criador de uma fenomenologia analítica em que se estabelece uma analogia entre atitudes emotivas conscientes e atitudes intelectuais visto que ambas poderiam ser consideradas corretas ou incorretas do ponto de vista moral - e na qual ele destacava a primazia do intencional (que teria sido negligenciado pela filosofia moderna centrada no intelectual). Tal raciocínio o levou a propor uma ética fundamentada "na analogia que pensa existir entre atitudes intelectuais e emotivas", pois "Brentano considerava que podemos estar imediatamente cientes da correção de algumas de nossas atitudes emotivas, tal como podemos estar imediatamente cientes da correção (i.e., da verdade) de algumas de nossas atitudes intelectuais", sendo que "[em] cada caso, a correção consiste numa relação apropriada ou adequada entre a atitude e o seu objeto" (Mautner, 2010f: 126).

Brentano pode ser visto também como um dos principais representantes da racionalidade analítica porque criticou a obscuridade das argumentações filosóficas dos continentais, crítica que continua com o movimento da lógica formal do neopositivismo, representado por Rudolf Carnap. Este, em um famoso ensaio, propõe um método para superar a problemática metafísica constituída pela análise lógica da linguagem, o qual mostraria que os enunciados metafísicos são, de fato, enunciados sem sentido, pois não poderiam ser nem corroborados nem refutados empiricamente (Carnap, 1932). Tradição que continua com a própria fenomenologia de Edmund Husserl, que adota a tese da intencionalidade da consciência de Brentano e concebe a prática filosófica como "'filosofia científica', fundada na lógica, sobre os resultados das ciências naturais e exatas" (D'Agostini, 1997: 2).

No segundo percurso se situa a tradição continental, que começou com Wilhelm Dilthey, formulador da oposição entre ciências naturais (Naturwissenschaften), essencialmente explicativas, e ciências do espírito (Geisteswissenschaften), basicamente interpretativas. Tal tradição prosseguiu com a hermenêutica de Martin Heidegger e Hans Georg Gadamer, que concebia, ao contrário, a filosofia como "filosofia humanística", isto é, que "considera[va] determinante a história e pensa[va] a lógica como 'arte do logos' ou 'disciplina do conceito', mais do que como cálculo ou computação"; ou seja, que visava à "superação da antítese entre cultura científica e cultura humanista" (D'Agostini, 1997: 2). 
Sem querer detalhar profundamente as diversas avaliações da relação entre discurso filosófico e discurso científico (ou entre analíticos e continentais), aqui parece suficiente lembrar que, atualmente, há relativo consenso sobre o fato de ambas as tradições se referirem - para aceitá-la ou para criticá-la - ao linguistic turn (guinada linguística) em filosofia, representado pela tentativa assinalada por Rorty (1967) - de construir uma teoria do significado e descrever, de forma sistemática, nossos modos de pensar o real. De fato, a guinada linguística - como já vimos falando a respeito da dialética entre paradigma da vida e paradigma da linguagem - "envolve todas as correntes do pensamento contemporâneo", embora esse reconhecimento não impeça que "a questão história-teoria", que se desenvolve no contexto "da antítese entre estilo analítico e estilo continental", permaneça de fato "não resolvida" (D'Agostini, 1997: 15-16).

Assim, nesse movimento, que tenta superar a oposição entre analíticos e continentais e pode ser visto também como uma das características distintivas do pensamento vivente e da vigência do paradigma da vida, parece ser possível inscrever o surgimento da bioética e das éticas aplicadas em geral, ou seja, da "ética prática" (Singer, 1994), a qual pode ser vista como o produto de uma espécie de síntese entre as duas tradições e suas construções. Sem entrar no mérito da pertinência e legitimidade dessa denominação, que compara uma corrente filosófica - representada pela filosofia dita analítica - e uma distinção territorial - referida ao continente europeu - e que refletiria "a tendência, por parte da filosofia analítica, [de] se apresentar como a única verdadeira filosofia nos países de língua anglo-saxônica", a ética prática pode ser vista como um campo tensional em que as duas correntes se relacionam, podendo-se dizer também que a ética prática constitui uma forma particular de "entrelaçamento de teoria e ética" (D’Agostini, 1997: 3, 10).

Entretanto, a declaração de uma superação da dialética entre analíticos e continentais pode ser interpretada - quando comparada com o problema da relação entre a dimensão descritiva e a dimensão prescritiva da ética - como, em realidade, mera - e não necessariamente legítima - redução da complexidade da dinâmica dessa superação, isto é, simples subsunção do aspecto descritivo e compreensivo ao aspecto prescritivo. 
Essa operação lógica subjacente está indicada - pelo menos indiretamente na expressão primado da ética, entendendo-se tal primado como uma espécie de deslocamento em sentido pragmático, sobretudo por quem deve tomar decisões concretas (como na prática clínica), processo inscrito no contexto daquilo que pode ser visto como "uma reabilitação da filosofia contra a razão científico-tecnocrática" (D’Agostini, 1997: 10). Ou, então, como a emergência de um "tipo de argumentação híbrida, que é ao mesmo tempo históricohermenêutica e lógico-analítica" (D'Agostini, 1997: 14). De qualquer maneira, essa questão fica, por enquanto, em aberto, mas poder-se-ia lembrar que, no plano do saber-fazer científico - ou, melhor dito, tecnocientífico - aplicado ao mundo da vida, temos a emergência de outro paradigma, o paradigma biotecnocientífico, que deve ser distinto tanto do paradigma da linguagem como do paradigma da vida, por incluir, em seu conceito, a dimensão técnica ou poiética. Deve-se, portanto, evitar a atribuição de uma conotação vitalista e, assim, todas as consequências indesejadas decorrentes de uma operação desse tipo, como poderia ser aquela da emergência de uma nova dupla problemática: biopolítica e tanatopolítica, como veremos a seguir.

\section{Biopoder, biopolítica, tanatopolítica e paradigma imunitário}

Para Giorgio Agamben (1998), a dupla biopolítica-tanatopolítica remeteria ao conceito de vida nua, entendida como algo ao mesmo tempo natural e capturado por um fora não natural, representado pelo biopoder - já estudado por Foucault (1976) -, que criaria uma relação de inclusão a qual é também, paradoxalmente, de exclusão. Ou seja, a vida nua remeteria a uma concepção de vida que é diretamente política porque, nela, a vida estaria destinada, em última instância, à morte, não por motivos naturais, decorrentes da finitude e da vulnerabilidade humana, mas por questões biopolíticas. E poderíamos acrescentar: biotecnocientíficas - graças às quais a vida desprotegida, de fato vulnerada, se torna a forma de vida dominante, sendo apropriada pelos dispositivos de biopoder e fazendo com que, no plano biopolítico, o estado de exceção se torne regra. Por isso, de acordo ainda com Agamben (1998), a principal consequência política desse movimento - ao mesmo tempo biopolítico e tanatopolítico - seria a indistinção ou um continuum entre democracia e totalitarismo, de onde emergiria um destinatário chamado Homo sacer. 
O outro filósofo da chamada Italian theory, que vem se debruçando sobre a relação biopolítica-tanatopolítica, é o já lembrado Roberto Esposito, para quem, por detrás do paradigma biopolítico, existiria um "paradigma imunitário", que inverteria as "relações de prevalência entre poder e vida" e cuja "metáfora vital [permitiria] a passagem do político ao biopolítico" (Calabrò, 2012: 106). Essa inversão poderia explicar, por exemplo, uma prática e ideologia como a nacional-socialista, na qual "o intento protetor da vida se inverte em seu contrário: na negação da vida", como foi certamente o caso do extermínio em massa representado pela Shoah, guiado pela exigência de proteger "a pretensa qualidade da vida humana mesmo ao custo da morte de 'agentes patógenos' que, se deixados em vida, só poderiam 'infectar' aquela vida que se pretende salvar". E isso aparentemente de acordo com a ética hipocrática, pois "a lógica dos médicos nazistas (...) precisava conservar sempre e de qualquer maneira a parte saudável do corpo político, não permitindo que enxertos ou cruzamentos biológicos pudessem prejudicar ou contaminar a pureza da raça" (Calabrò, 2012: 108).

Feitas essas considerações problemáticas mais gerais, exemplificadas pela dialética entre biopolítica e tanatopolítica - sustentada pelo paradigma imunitário - e que constituem, de algum modo, o contexto discursivo mais apropriado para abordar os problemas concretos e complexos da bioética, assim como suas relações com a biopolítica e a biotecnociência, podemos destacar alguns problemas particulares em suspenso (ou não resolvidos) sobre os tipos de relação existentes (ou que deveriam existir) entre ética e metaética, bioética e metabioética.

\section{Alguns problemas teóricos em suspenso}

O primeiro problema em suspenso é de tipo sociológico e se refere a uma atitude geral de rechaço ou desconfiança com relação à pertinência e à legitimidade da análise metaética, o que pode ser visto também como uma misologia, ou aversão ao conceito. Historicamente, essa misologia se apresenta como produto de uma desconfiança pós-moderna, cujo lema seria, de acordo com Jean-François Lyotard (1979: 8-14), "sejam operacionais, isto é, comensuráveis, ou desapareçam", pois "o saber é e será produzido para ser vendido, e é e será consumido para ser valorizado em uma nova produção; 
nos dois casos: para ser trocado"; ou seja, porque o saber ter-se-ia tornado "a principal força produtiva". Tal atitude seria típica do "homem de ação" e corresponderia a uma "perda de crédito das grandes teorias", o que teria levado a um "reino da afetividade sem conceito", devido "a sua constitutiva ausência de espírito crítico", de fato reduzido "muitas vezes à mera ideologia" (Benoist, 2011b: 40-41).

O segundo problema - aparentemente mais sério do ponto de vista dos desafios à metaética - é epistemológico e diz respeito à relação referencial entre conceitos e objetos, ou - se preferirmos - entre simbólico e real, pois tal relação estaria sempre (ou estruturalmente) marcada por uma falta, visto que "a própria condição do alcance real de nossos conceitos é sua ultrapassagem pelo real", problema para o qual não teríamos solução porque de fato "não temos conceitos" para dar conta de tal ultrapassagem (Benoist, 2011b: 35).

O terceiro problema é de tipo propriamente pragmático, pois se refere à possível e efetiva relação entre conceitos e experiência, uma vez que os conceitos podem não dar conta de toda a experiência que devem e pretendem representar. De acordo com a teoria dos atos de fala, existe o aspecto da ação dos conceitos, diante, por exemplo, da ação da sensibilidade. Mas existe também o problema metaético da legitimidade da noção de conceito ante a noção de sensibilidade.

Tal problema parece patente no caso das normas, em que deveríamos ter presente que:

1) "sempre que raciocinamos podemos errar";

2) "sempre existe conceito onde uma norma é aplicada à experiência";

3) "sobre nossos conceitos pesa, em geral, uma forma de suspeita", pois podemos sempre perguntar se os conceitos utilizados "são capazes [de] atingir o real", visto que "o real nem sempre se apresenta no encontro do conceito que lhe aplicamos, ou tentamos lhe aplicar"; ou seja, porque:

4) "devemos assumir esta possibilidade de que um conceito seja vazio" (Benoist, 2011b: 58-69).

Nesse contexto crítico geral (indicado pela desconfiança dita pós-moderna) sobre o alcance e os limites da metaética, deve-se destacar uma de suas 
ferramentas utilizadas nas tentativas de superar essa desconfiança diante das possibilidades de solução da conflituosidade moral abordada pela bioética, inclusive pela bioética clínica. Trata-se da ferramenta problemática, já lembrada e conhecida como análise racional e imparcial, considerada necessária para se abordar corretamente um conflito concreto, pois ela nos permitiria lembrar que

o conceito implica [sempre] certo distanciamento [e que] sempre existe conceito onde se instaura essa distância lógica, que é aquela que existe entre o verdadeiro e o falso, ou (...) para generalizar (...), inclusive em direção às atitudes práticas em que estas se tornam ações no sentido (...) do correto e do incorreto. (Benoist, 2011b: 70-71, destaques do original)

É esse tipo de questão que a metaética em geral e a análise conceitual de maneira específica pretendem analisar, sendo que ambas podem ser vistas como ferramentas indispensáveis da própria bioética clínica para esclarecer os termos de seus conflitos e dilemas morais - o que poderia ser visto também como condição necessária (embora não suficiente) para resolver um conflito graças a essa consideração analítica e crítica de seus argumentos.

\section{A Bioética Clínica, suas Questões Metaéticas e Metabioéticas}

Quando se integram as dimensões da teoria e da prática na identificação da identidade da bioética clínica, esta pode ser vista como o campo de saberes e de reflexões capazes de detectar, analisar, compreender e tentar resolver os conflitos morais que se dão no tratamento (ou cuidado) individual (ou pessoal) de pacientes. Ou seja, a bioética clínica pode ser conceituada como um campo resultante da inter-relação de "teoria e prática, experiência e reflexão"(Georgetown University Medical Center, s.d.).

Mas a bioética clínica tem um antecedente histórico na forma de ética aplicada chamada "ética clínica", termo utilizado por Joseph Fletcher em 1976 para "designar a prática da decisão clínica em situação problemática no plano moral", que deveria "refletir a natureza específica da bioética, aplicada na clínica ou em situações centradas no paciente". ${ }^{3}$ Em realidade, a bioética clínica pode ser vista como a parte da bioética ou - como preferem alguns -

${ }^{3}<$ www.jiffnotes.com/a_study_guides/book_notes/ewb_05/ewb_05_02192.html>. Acesso em: 10 out. 2013. 
uma das bioéticas (Neves \& Lima, 2005) referentes à moralidade de um conjunto bastante vasto de práticas, que se referem ao tratamento ou cuidado de pacientes e devem ser capazes não somente de resolver em termos práticos um conflito, mas também de abordá-lo teoricamente para justificar a decisão pela qual se pretende resolvê-lo. Ou seja, a bioética clínica deve saber identificar e analisar conceitos e argumentos envolvidos nesse tipo específico de interrelação, inscrita na conflituosidade social, que se estabelece entre agentes e pacientes morais, isto é, entre os autores dos atos e seus destinatários (diretos ou indiretos).

Assim, a bioética clínica - como qualquer âmbito da bioética - se depara necessariamente com questões conceituais e dúvidas acerca da decisão correta a ser tomada numa inter-relação, como a que se estabelece, por exemplo, entre médico e paciente, que deve em princípio ser horizontal e dialógica (ou, melhor dito, horizontal porque dialógica), evitando, portanto, seja atitudes autoritárias, seja atitudes paternalistas. E isso devido a seu objetivo principal, que consiste em resolver conflitos no âmbito da prática clínica graças a ações de tipo inclusivo e comunicativo entre pares - e que não pode se dar em uma relação hierárquica autoritária ou paternalista em que o médico toma a decisão que considera correta, sem a participação ou pelo menos o consentimento de seu paciente. Assim, pode-se dizer que a bioética clínica lida com conflitos morais que devem em princípio ser resolvidos consensualmente, ou - tendo em conta as ambiguidades e dificuldades do termo consenso - por negociações e acordos. E isso respeitando os interesses moralmente legítimos envolvidos e a cláusula de que os participantes do acordo sejam suficientemente racionais ou razoáveis. Ou seja, participantes suficientemente imparciais e não impelidos por emoções incontroláveis ou crenças inquestionáveis na escolha da melhor solução possível do conflito em situações em que haja diversas concepções do correto e incorreto, como pretende indicar o termo pluralismo moral aplicado às sociedades complexas contemporâneas.

Entretanto, aqui surge o problema conceitual e lógico dos dilemas morais enfrentados na prática clínica, conflitos de difícil solução (quando não impossíveis de resolver sem alguma arbitrariedade) por se tratar de "situações em que cada curso possível de ação viola certo princípio moral que também é, por seu lado, obrigatório" (Blackburn, 1997e: 102). Desse 
modo, se considerarmos as situações que podemos qualificar de esquizofrênicas, representadas pelos autênticos dilemas morais, veremos que estes podem representar um sério desafio para quem deva tomar uma decisão difícil nesse tipo de situação, sobretudo para qualquer clínico consciencioso.

Em realidade, um dilema não tem propriamente uma solução decorrente de um raciocínio lógico cogente (por isso é um di-lema), e as soluções encontradas sempre serão parcialmente arbitrárias (indicadas por isso pela imagem da escolha de Sofia), visto que, quando se age no respeito de algum princípio moral importante (como um dever), acaba-se por infringir outro princípio moral igualmente importante (que pode ser outro dever). Assim, uma tomada de decisão em situação moralmente dilemática parece situar-se sempre no campo da tragédia, uma vez que implica escolher entre soluções acerca das quais não se sabe sempre muito bem dizer, de antemão, qual é a mais correta ou qual é a mais errada - como nos casos de ter que escolher quem deve viver e quem não, quem merece cuidado e quem merece menos ou nenhum em determinadas circunstâncias, como aquelas de escassez de meios ou de recursos.

Em outros termos, as ações abordadas pela bioética clínica são práticas que se inscrevem em um cenário caracterizado pela conflituosidade que, para ser legitimamente resolvida, deve ser aceita como constitutiva das próprias interrelações humanas e, por isso, demanda reflexão sobre o processo que leva do conflito à sua possível resolução, e também o conhecimento dos possíveis argumentos envolvidos, de seus conceitos e dos agenciamentos entre eles (que podem ser cogentes ou não). E isso graças à análise crítica dos conceitos utilizados e de seus significados e modos de se articularem entre si nas várias argumentações em campo.

Mas esse poderia ser um campo legítimo daquela que chamaríamos, com mais propriedade, de metabioética, entendida aqui como a análise da linguagem da bioética e das questões conceituais e argumentativas envolvidas na moralidade estudada também pela bioética clínica. Esta, como vimos, pode ser entendida como subconjunto da bioética como um todo, começando pela análise do próprio conceito problemático de vida, que analisamos em outro escrito (Schramm, 2009) e não será abordado especificamente aqui. 


\section{Metaética e metabioética}

A metabioética pode ser entendida como a parte metaética do saber bioético, ou seja, como o conjunto de ferramentas utilizadas pela(s) bioética(s) em sua(s) análise(s) dos conflitos no campo das ciências da vida e da saúde. Consideradas tanto em suas dimensões descritiva e normativa quanto em seus contextos reais específicos de conflituosidade, tais ferramentas conformam os próprios conceitos utilizados e os raciocínios elaborados graças a eles.

Em outros termos, a metabioética pode ser vista como uma forma de conhecimento que é uma parte da metaética, ${ }^{4}$ a qual é a parte da ética que analisa a linguagem moral (da mesma forma que a metalinguagem é a análise da linguagem). Ao passo que a ética pode ser entendida também - de acordo com uma sugestão de Ricardo Maliandi - como "tematização do ethos", isto é, como aquela parte da ética que "tem caráter reflexivo" e é, também, "parte constitutiva do ethos" ou parte "do objeto de tal reflexão" - o que nos levaria "ao paradoxo de que a ética, como tematização do ethos, resulta ser, ao mesmo tempo, tematização de si mesma" (Maliandi, 2004: 17).

Mas considerando essa relação entre ethos e tematização do ethos - que é, por isso, uma relação que poderíamos chamar de topológica -, pode-se considerar a metaética como "disciplina filosófica que tematiza e procura resolver ou, pelo menos, esclarecer os problemas morais" e, portanto, deve enfrentar "um conglomerado de problemas" que se referem "a algum tipo de relação conflituosa" (Maliandi, 2004: 11). Ou seja, é essa conflituosidade intrínseca às relações humanas (já destacada por Maquiavel) que constitui o referente ao qual se aplica tanto a ética (diretamente) quanto a metaética (indiretamente), o que implica admitir, por um lado, "a inevitabilidade [a priori] dos conflitos" e, por outro, "uma pluralidade de princípios" para poder dar conta deles e, ao mesmo tempo, se dar conta de que isso "exige maximizar a harmonia entre eles" (Maliandi, 2004: 12).

Assim, em suas interrogações, a metaética - entendida não mais em seu sentido estrito, mas ampliado - deverá responder a perguntas do tipo:

\footnotetext{
${ }^{4}$ Seria possível afirmar também o contrário, dizendo que a metaética está se tornando parte da metabioética, porque - como vimos - o paradigma linguístico pode ser visto como vinculado a um paradigma da vida, ou como um subconjunto deste. Aqui deixaremos, no entanto, a questão em aberto.
} 
1) O que significa dizer que algo é bom, correto ou justo?

2) Como conhecemos o que está certo ou errado?

3) Como as atitudes consideradas morais podem motivar uma ação?

E, ademais:

4) O que são os valores? Existem valores objetivos? Absolutos?

5) O que é uma norma ética, e como são criadas as normas?

Todas essas perguntas (a lista não é, evidentemente, exaustiva) fazem parte do âmbito de reflexão da ética e da bioética (que são a metaética e a metabioética), reflexão que visa a descrever as normas em vigor, mas também fundamentá-las e, eventualmente, questionar as fundamentações vigentes (como exige o pensamento dito crítico). Inclusive esclarecendo o sentido e o uso dos termos da linguagem moral vigente, para poder confrontá-la com eventuais alternativas em gestação no próprio ethos entendido também - de acordo com a sugestão de Maliandi (2004) - como uma tematização de si mesmo.

Por isso, pode-se dizer, em síntese, que metaética e metabioética, entendidas como tematizações da ética e da bioética - mas inseparáveis do próprio ethos -, implicarão necessariamente ferramentas analíticas e interpretativas como a explicitação dos conceitos, as investigações lógico-semânticas que lhes dizem respeito, sistematizações teóricas e análises das eventuais logomaquias em campo, para que se possa reconstruir, de forma pertinente e crítica, o ethos autorreflexivo ao qual se refere a bioética e, em particular, a metabioética. Mas implicarão também enfrentar a prática das inter-relações quando isso for julgado necessário (por exemplo, na abordagem de um conflito específico no set da prática clínica).

Assim sendo, e partindo do pressuposto de que existe um saber moral préfilosófico que qualquer ser racional dotado de vontade, e independentemente da tematização ética em pauta, possui, mas só pode ser expresso pela terminologia e pela metodologia filosóficas, Maliandi $(2004: 29,34)$ considera que a ética deveria ser entendida, em última análise, como "a reconstrução normativa crítica de um saber intuitivo, pré-teórico", reconstrução que, "ao mesmo tempo que explicita [este] saber pré-teórico (...) procura tornar compreensível 
o fato complexo da moralidade". Por isso, para o filósofo argentino haveria "no ethos uma tensão constante entre as incumbências do racional e do emocional, ou seja, uma dicotomia cabal entre logos e pathos" (Maliandi, 2004: 44). Em suma, haveria uma dialética entre razão e emoção, que a ética contemporânea não pode se eximir de enfrentar se quiser estar à altura da complexidade real dos conflitos vigentes nas inter-relações humanas, inclusive aquelas construídas na prática clínica, na qual é sempre possível a falta de consenso entre os atores envolvidos.

\section{A pertinência do método da análise conceitual da metabioética e o caso dos pseudoconceitos}

Se uma função certamente importante dos conceitos é se referir ao real e tentar entendê-lo, e da análise conceitual é esclarecer a maneira como usamos os conceitos para tentar dar conta de tal referência e de tal entendimento, diante de conceitos mal definidos, ou pseudoconceitos, ficamos muitas vezes sem saber o que se deveria pensar (ou representar ou construir) por meio deles. Ou seja, ficamos perplexos diante da "dimensão real, ou não, daquilo que pensamos" (Benoist, 2011b: 9).

Diante desse mal-estar na presença de conceitos inconsistentes ou mal definidos, e que não sabemos bem dizer para que podem realmente servir, a análise conceitual - que pode ser entendida também como "o verdadeiro nome da filosofia" (Benoist, 2011b: 10) - parece mostrar que os conceitos dependem também - como já vimos - de sua referência ao real, pois do ponto de vista de uma possível "filosofia realista" capaz de "compreender o que (...) fazemos com aquilo que temos" (Benoist, 2011a: 10), é no real que se situa, em última instância, nossa existência e aquela dos outros com os quais interagimos.

Mas essa referência ao real, aparentemente evidente por fazer parte de nossa experiência, é de fato também problemática, senão paradoxal, teoricamente, como indica a polissemia do próprio termo real. De fato, real pode significar inter alia "verdadeiro", "concreto", "que existe realmente", "que não é falso, ilusório ou artificial; genuíno" (Houaiss \& Vilar, 2001: 2.391). Ademais, o termo pode indicar algo que "age efetivamente" e que se opõe ao "relativo", ao "ideal", ao "possível"; referindo-se, portanto, "às coisas como são, e não como poderiam ser ou deveriam ser", mas também ao que se opõe ao "relativo", 
ao "fenomênico" e ao "aparente". Por fim, não se deve esquecer que real é muitas vezes concebido como sinônimo perfeito de realidade, com o sentido de "caráter daquilo que é real" ou de "o que é real", caso em que se pode falar em "anfibologia das palavras real e realidade", a qual pode ser considerada causa de paralogismos (Lalande, 1972a: 894).

Um caso interessante dessa anfibologia é a concepção e o uso do termo real feitos pelo psicanalista Jacques Lacan ao longo de sua obra. Para Lacan, por um lado haveria uma congruência entre real e simbólico, pois "tudo que é real é racional", e, por outro, o real parece se opor ao simbólico, ficando além deste (ao qual não se ajustaria), pois "o real [é] o âmbito daquilo que subsiste fora da simbolização (...) ele está lá, idêntico a sua existência [e sendo] rumor onde tudo pode ser entendido" (Lacan, 1966: 226, 338). Entretanto, para a concepção topológica de Lacan, existe também uma ligação entre real e ética. Por exemplo, no Seminário XI ele afirma que "o estatuto do inconsciente é ético" e "frágil no plano ôntico", ou - mais diretamente - "o estatuto do inconsciente é ético, não ôntico", porque o inconsciente "se mostra" (Lacan, 1973: 31-35).

Segundo a psicanalista Alenka Zupančič, para Lacan tratava-se de "vincular a ética da psicanálise à ética do Real (...) no sentido de que o real não se refere ao ser, mas a algo que, embora não exista na maneira do ser, tem consequências negativas para o ser" e, sobretudo - o que mais nos interessa aqui -, "o Real não é o 'além do discurso (ou da linguagem)'”, mas o que é capturado no discurso e transforma sua "estrutura e lógica", visto que "o Real é desde sempre aqui, atrás de nós, em nós, e que articula aquela estrutura com a qual tentamos aproximá-lo" (Zupančič, 2012: 15-16).

Diante dessas dificuldades, parece mais promissor considerar que, no caso da bioética clínica, a análise conceitual tenha não tanto o papel de estabelecer uma relação "correta" entre fatos reais e sua simbolização (que é de fato um problema epistemológico, além de psicológico), mas, sobretudo, o valor de método, consistente na "elucidação do sentido das questões que dizem respeito à 'realidade' deste ou daquele gênero de coisas ou seres" (Benoist, 2011a: 9). E isso tendo em conta que todo conceito é sempre finito, limitado a uma porção do real, o que impede a determinado conceito dar conta das outras porções do real, como bem mostram a história das ciências e a sucessão de seus paradigmas legítimos que se estabeleceram e declinaram ao longo do tempo. 
Há, portanto, conceitos que são pertinentes e outros que não o são quando nos referimos a determinada realidade conflituosa, como pode ser aquela abordada pela bioética clínica. Ou, dito diversamente, todo conceito é sempre finito, isto é, limitado a uma porção de realidade, e sua capacidade de dar conta de determinada porção de realidade parece ser exatamente o que o impede de dar conta das outras porções de realidade. Pois todo conceito depende do ponto de vista aplicado a uma porção de realidade, e não existe um ponto de vista concreto que contenha todos os pontos de vista possíveis sobre o real. Em suma, porque existem conceitos que são pertinentes e outros que não o são quando nos referimos a determinada realidade, como pode ser aquela abordada pela bioética clínica. Ademais, há partes da realidade para as quais não dispomos de conceitos e que indicamos justamente pelo denso termo real (no segundo sentido lacaniano aqui indicado).

Em síntese, a bioética clínica (mas também a bioética em geral) parece ter que lidar com problemas conflituosos concretos, argumentos e justificativas que sustentem suas decisões, elaborações construídas graças a conceitos e encadeamentos de conceitos e de argumentos, que podem ser analisados pela metabioética. Esta, longe de ser desnecessária (como supostamente ter-se-ia tornado a metaética depois do aparecimento do paradigma das éticas aplicadas), deve ser vista como uma ferramenta indispensável da própria ética prática e da bioética.

De acordo com a teoria dos signos - ou semiologia - de Ferdinand de Saussure ([1916] 1974), os conceitos conformam os significados dos signos e estes se referem a outros signos, dos quais devem se diferenciar para que haja sentido inteligível num discurso. Esta é a razão pela qual uma metabioética atenta deverá sempre ter em devida conta também tais características semióticas dos problemas morais, que se referem à análise formal dos argumentos morais utilizados pelos envolvidos, detectando suas estruturas semânticas, narrativas e temáticas que os caracterizam, para "tentar dar conta das articulações do discurso concebido como um todo de significação" (Mucchielli, 2011a: 243).

\section{Para Não Concluir}

Como tentamos mostrar ao longo deste ensaio, a problematização metabioética e a ferramenta conhecida como análise conceitual - concebida como 
ferramenta tanto da tradicional metaética como da metabioética - podem ser vistas como meios importantes para conhecer os juízos que comandam uma ação moral - graças à identificação dos conceitos envolvidos, à análise de seu encadeamento lógico nos argumentos morais produzidos para tentar justificar um determinado ato, e ao tipo de relação estabelecido com valores e princípios que orientam tal ação e permitem dizer se ela é moralmente correta ou não.

Em particular, as ferramentas da metabioética podem ser importantes para a própria bioética clínica, não somente para que os seus agentes morais possam utilizar corretamente os conceitos e raciocinar de maneira adequada (ou cogente), isto é, em substância, para se comunicarem entre si; mas também porque a escolha da cogência e de um método adequado, considerados necessários para analisar criticamente os conflitos morais que surgem na prática clínica, parece indispensável para um agir moral correto. Caso contrário, não saberíamos do que estamos de fato falando e, portanto, o que fazer. Ademais, isso é necessário quando se pretende articular o simbólico e o real de forma pertinente e significativa - isto é, que faça sentido para os envolvidos em um conflito de tipo moral -, permitindo enfrentar o problema de saber dizer, por exemplo, se uma afirmação de tipo moral é verdadeira ou falsa, pertinente ou não, justificada ou não. Ou seja, correta ou incorreta em uma situação concreta.

Portanto, existe uma preocupação teórica que não pode ser afastada (ou recalcada) facilmente, pois, de qualquer maneira, temos um vínculo "essencial com o real" tanto "nos pensamentos falsos" (e seus "conceitos vazios") quanto nos "pensamentos verdadeiros" (e seus "conceitos "plenos"), e esse "vínculo" pode ser visto como "um dado fundamental daquilo que chamamos 'pensamento'", pois "um pensamento só pode ser incorreto na medida em que ele está conectado com o real" (Benoist, 2011b: 73). Dito com outros termos, só parece existir conhecimento de um problema se o pensamento que o analisa for correto, e isso pode ser visto como condição necessária para que se possa dar uma resposta adequada a tal problema. Ou seja, existe um "vínculo constitutivo dos conceitos com a realidade, tanto no sucesso quanto no fracasso em sua aplicação" (Benoist, 2011b: 74). E é essa a ideia principal de uma filosofia realista para nossa problemática metaética ampliada, pois o principal objetivo de sua ferramenta, constituída pela análise conceitual, parece ser aquele de tentar "atingir a facticidade mesma dos conceitos (...) 
questionados em seu ser fundamentalmente mundano" e "fazer aparecer [as] divisões humanas primordiais das coisas que constituem muitas vezes a base de nossos conceitos", tentando assim "pôr em evidência suas consequências, desejáveis ou indesejáveis" (Benoist, 2011b: 202-203).

Finalizando, a tentativa de considerar a dimensão pragmática dos conceitos utilizados em bioética pode ser vista como uma característica daquela que podemos chamar a realidade do pensamento, a qual implica que se considere sua facticidade e suas implicações para a qualidade de vida de indivíduos e populações humanas. Sem esquecer o fato de que existem conceitos que podem se revelar conceitos verdadeiros ou pseudoconceitos, quando aplicados a situações concretas. Assim, uma condição necessária para que "nossos conceitos possam continuar sendo chamados de 'conceitos'" é que eles "conservem, em sua zona de pertinência respectiva, um poder discriminante" (Benoist, 2011b:173), para que não sejam vistos como conceitos vazios ou, simplesmente, confusos. Caso contrário, dificilmente serviriam como ferramentas pertinentes e legítimas da bioética clínica. Enfim, é somente submetendo-se um conceito "à prova de situações inéditas que tais potencialidades aparecerão ou não, e que sua zona de pertinência se configurará e se desvelará" (Benoist, 2011b: 180). 